\title{
Cost, energy and GHG emission assessment for microbial biodiesel production through valorization of municipal sludge and crude glycerol
}

\author{
Lalit R. Kumar ${ }^{\text {a }}$,Sravan K. Yellapu ${ }^{\text {a }}$, R.D. Tyagi ${ }^{a}{ }^{{ }_{*}}$, Patrick Drogui ${ }^{a}$ \\ a INRS Eau, Terre et Environnement, 490, rue de la Couronne, Québec G1K 9A9, Canada
}

\section{A R T ICLE INFO}

\section{Keywords}

Blended biodiesel

Waste carbon sources

Economic evaluation

INRS process

Conventional process

\begin{abstract}
A B S T R A C T
In this study, cost simulations were made based on 20 million L blended biodiesel B-10 production per year using INRS and conventional process. In case of INRS process, microbial lipid was produced by T. oleaginosus using washed municipal secondary sludge fortified with crude glycerol while lipid was extracted from wet biomass using biodegradable surfactant and petroleum-diesel (PD). The conventional process uses commercial substrates for lipid production and organic solvents for lipid extraction from dry biomass. The unit B-10 production cost of INRS process was estimated to be $\$ 0.72 / \mathrm{L}$ for an annual capacity of 20 million $\mathrm{L}$, which is 9.5 times more economical than conventional biodiesel production process. For INRS process, the unit B-10 biodiesel production cost was sensitive to plant capacity and lipid productivity during the fermentation. INRS process exhibited positive net energy gain and positive GHG capture, which proves to be energetically and environmentally viable.
\end{abstract}

\section{Introduction}

The depletion of known petroleum reserves and rising energy demand make renewable energy sources more attractive. Biodiesel, fatty acid methyl esters (FAMEs), has grabbed great attention due to the advantages such as it is renewable, sustainable, environmentally-friendly (burns much cleaner than petroleum diesel), compatible with current commercial diesel engines, as well as has excellent lubricity and could provide the energy density similar to diesel. Alternative biodiesel feedstocks need to be investigated due to the increasing price of edible oil and limited feedstock sources. Biodiesel production from sunflower and soybean oil has disadvantages including dependence on climatic conditions, high labour costs, use of pesticides and herbicides. Therefore, it has forced the researchers and engineers to look for a replacement of the conventional oils and lipids as raw materials, which should be abundant, sustainable, and economically favorable. Oleaginous microorganisms have shown a great advantage as a lipid source due to their faster growth rate and high lipid contents (up to $80 \%$ microorganism dry weight) compared to oilseed crops and animal fat. However, techno-economic evaluation of microbial oil production using glucose as media revealed that the unit production cost of biodiesel using microbial oil production with glucose as substrate was estimated to be $\$ 5.9 / \mathrm{kg}$ biodiesel while commercial biodiesel price was $\$ 1.2 / \mathrm{L}$ (Apostolakou et al., 2009). Also, biomass settling and lipid extraction has been conducted by centrifugation and utilization of toxic and expensive solvents, respectively. However, solvent application necessitates evapo- ration for solvent recovery, which further increases the cost of biodiesel production (Yellapu et al., 2018).

In Institut National de la Recherche Scientifique (INRS) lab, a novel biodiesel production process has been developed where lipid production has been accomplished using renewable waste carbon sources such as crude glycerol and municipal sludge while lipid extraction has been achieved using biodegradable surfactant (Zhang et al., 2018; Yellapu et al., 2019b). The wastewater sludge contains biodegradable carbon and nutrients (nitrogen, phosphorus and trace elements, etc.), which makes it a perfect raw material for the growth of oleaginous microorganisms (Zhang et al., 2018). On the other hand, crude glycerol generated as a by-product of biodiesel industry also poses a problem because crude glycerol is contaminated with various elements $(\mathrm{Ku}$ mar et al., 2019a). The crude glycerol must be purified before any industrial use and the cost of purification is very high, which makes the process of glycerol utilization uneconomical (Chen et al., 2018b). Therefore, there is a need to develop a process where there is no need to purify the crude glycerol solution or require minimum purification. Crude glycerol serves as a very good carbon source for bioconversion (Kuttiraja et al., 2016). Co-fermentation of crude glycerol (carbon source) and wastewater sludge (carbon and nutrient sources) for lipid production using oleaginous microorganisms provides the solution to highly reduce the biodiesel production cost using heterotrophic microorganisms and addresses the problem of food vs fuel crisis. In INRS lab, biomass settling has been performed using chemical coagulant and bio-flocculant (extracellular polymeric substances or EPS). The cell

\footnotetext{
* Corresponding author.

E-mail address: Rd.tyagi@ete.inrs.ca (R.D. Tyagi)
} 
wall disruption was successfully performed by using free nitrous acid (FNA) and the bio-surfactant n-lauryl sarcosine (N-LS). The released lipid after cell wall disruption was separated by phase separation with the aid of petroleum-diesel (PD), which eliminated the requirement of organic solvents like chloroform, methanol and hexane. Moreover, there will be no requirement of blending of petroleum diesel with biodiesel (Yellapu et al., 2019b).

However, a reliable economic evaluation needs to be performed to verify the industrial feasibility of the INRS process. During the exercise of techno-economic evaluation, the study reveald the actual economic bottlenecks, which should be improved by the researcher for making the process (technology) economically feasible. This study investigated the industrial feasibility of biodiesel production from microbial oil, which in turn was produced using municipal sludge fortified with crude glycerol as a substrate. A techno-economic evaluation of the process developed in INRS lab was performed and important process parameters that impact the biodiesel production cost have been discussed in the study. To corroborate the environmental impact of the process, energy balance and greenhouse gas (GHG) emission balance have also been evaluated and the results were compared with the conventional biodiesel production process using microbial lipids.

\section{Methodology}

\subsection{Description of INRS process}

For the economic evaluation, the complete INRS process can be divided into five-unit operations: (1) Inoculum development (2) Production Fermenter (3) Biomass settling (4) Lipid extraction and recovery and (5) Trans-esterification.

\subsubsection{Inoculum development}

Seed fermentation was considered from Zhang et al. (2018) where inoculum development was accomplished at $28^{\circ} \mathrm{C}$ in $24 \mathrm{~h}$. The carbon source and nutrient source used in the medium were secondary municipal sludge while glycerol $(40 \mathrm{~g} / \mathrm{L})$ was used as the additional carbon source, whereas no additional nitrogen source and trace elements were added as sludge has enough nitrogen and trace metals for the microbial growth. Crude glycerol used during the fermentation had composition (w/w) of $78.22 \%$ glycerol, $2.63 \%$ soap, $2.52 \%$ ash, $12.15 \%$ methanol and $1.56 \%$ water. The strain used for lipid production was Trichosporon oleaginosus (Zhang et al., 2018). Municipal sludge with 5g/ $\mathrm{L}$ suspended solids (SS) were allowed to settle in a clarifier followed by centrifugation at $5000 \mathrm{~g}$ to concentrate the sludge to $35 \mathrm{~g} / \mathrm{L}$ (Zhang et al., 2018). Concentrated sludge was washed with tap water $(30 \mathrm{~L} / \mathrm{kg}$ sludge solids) to remove the heavy metals and other materials sticking to the sludge solids, which could be inhibitory for microbial cell growth (Zhang et al., 2018). The composition of heavy metals before and after washing is presented in Table 1a. The sludge was fortified with $4 \mathrm{M}$ $\mathrm{NaOH}$ to bring $\mathrm{pH}$ to 12 and was sterilized at $121^{\circ} \mathrm{C}$ for $30 \mathrm{~min}$. After cooling, $\mathrm{pH}$ was brought at 6.5 using $4 \mathrm{M} \mathrm{H}_{2} \mathrm{SO}_{4}$. Sterilized crude glycerol (glycerol was sterilization to remove methanol) was added to the pre-treated sludge.

Table 1a

Heavy metal concentration in the fermentation medium before and after sludge washing.

\begin{tabular}{lll}
\hline Heavy Metal & Before washing $(35 \mathrm{~g} / \mathrm{L} \mathrm{SS})$ & After washing $(35 \mathrm{~g} / \mathrm{L} \mathrm{SS})$ \\
\hline $\mathrm{Fe}(\mathrm{mg} / \mathrm{L})$ & 139.2 & 41.3 \\
$\mathrm{Mg}(\mathrm{mg} / \mathrm{L})$ & 45.8 & 10.1 \\
$\mathrm{Mn}(\mathrm{mg} / \mathrm{L})$ & 7.4 & 5.4 \\
$\mathrm{Ni}(\mathrm{mg} / \mathrm{L})$ & 0.8 & 0.5 \\
$\mathrm{Zn}(\mathrm{mg} / \mathrm{L})$ & 10.4 & 3.7 \\
$\mathrm{Cu}(\mathrm{mg} / \mathrm{L})$ & 6.8 & 4.2 \\
\hline
\end{tabular}

\subsubsection{Production fermenter}

Municipal sludge with $5 \mathrm{~g} / \mathrm{L}$ SS was allowed to settle in a clarifier followed by centrifugation at $5000 \mathrm{~g}$ to concentrate the sludge to $35 \mathrm{~g} /$ L (Zhang et al., 2018). Concentrated sludge was washed with tap water (30 L/ kg sludge solids) to remove the heavy metals and other materials sticking to sludge solids, which could be inhibitory for microbial cell growth (Zhang et al., 2018). The sludge $\mathrm{pH}$ was adjusted to 12 with $4 \mathrm{M} \mathrm{NaOH}$ and was sterilized at $121^{\circ} \mathrm{C}$ for $30 \mathrm{~min}$ and cooled to $28^{\circ} \mathrm{C}$. After addition of sterilized crude glycerol (sterilization done for removal of methanol), production fermenter was inoculated. Production fermenter of 500,000 L reactor with a working volume of $340327 \mathrm{~L}$ was used as the main production fermenter. The fermentation was conducted for $48 \mathrm{~h}$ at $28^{\circ} \mathrm{C}$ at $\mathrm{pH}$ of 6.5 . The fermentation operation was considered from Zhang et al. (2018) where lipid fermentation occurred in $48 \mathrm{~h}$ while $44.48 \mathrm{~g} / \mathrm{L}$ total biomass and $17.37 \mathrm{~g} / \mathrm{L}$ lipid biomass were produced using T. oleaginosus (Zhang et al., 2018). During the first $6-12 \mathrm{~h}$, DO (dissolved oxygen) concentration in the fermenter decreases from $90 \%$ to $35 \%$ and later it was maintained in the range of $25 \%-40 \%$ throughout fermentation (Zhang et al., 2018).

Two production fermenters of 500,000 L capacity were used for microbial lipid production for processing consecutive batches. A plant continuously operating for 350 days per year would result in 307 batches (time for processing one batch $60.08 \mathrm{~h}$ ) while the time between inoculation of two batches was $27.17 \mathrm{~h}$. The process timeline for processing of 1 batch has been indicated in Table $1 \mathrm{~b}$.

\subsubsection{Biomass settling}

In the last decade, various improvements in biomass harvesting technologies have been developed and applied such as centrifugation, flocculation, sedimentation, tangential flow filtration and electrolytic flocculation. Among all the technologies, centrifugation is the

Table 1b

Process Timeline for processing of 1 batch of B10 product using INRS process.

\begin{tabular}{|c|c|}
\hline Operation & Description \\
\hline FR-101 & Production Fermenter \\
\hline Cleaning in place & $\begin{array}{l}60 \text { min, Cleaning of equipment with } 1 \mathrm{M} \mathrm{NaOH} \text { solution } \\
\text { supplied at } 60^{\circ} \mathrm{C}\end{array}$ \\
\hline CHARGE Sludge & $60 \mathrm{~min}$, Charge washed sludge to production fermenter \\
\hline pH-12 & 15 min, $\mathrm{pH}$ adjustment with $4 \mathrm{M} \mathrm{NaOH}$ \\
\hline $\begin{array}{l}\text { Sterilization at } \\
121^{\circ} \mathrm{C}\end{array}$ & $90 \mathrm{~min}$ (including holding time of $30 \mathrm{~min}$ ) \\
\hline COOL & $90 \mathrm{~min}$, Cooling to $28^{\circ} \mathrm{C}$ \\
\hline pH-6.5 & 15 min, $\mathrm{pH}$ adjustment with $4 \mathrm{M} \mathrm{H}_{2} \mathrm{SO}_{4}$ \\
\hline CHARGE glycerol & $15 \mathrm{~min}$, Charge sterilized crude glycerol to main fermenter \\
\hline Inoculum & $60 \mathrm{~min}$ - Transfer inoculum from seed fermenter to main \\
\hline TRANSFER & fermenter \\
\hline Fermentation & Fermentation for $48 \mathrm{~h}$ at $28^{\circ} \mathrm{C}$. \\
\hline TRANSFER-OUT & $60 \mathrm{~min}$ - Transfer the fermented broth to a clarifier \\
\hline CLR-101 & Biomass settling in a clarifier \\
\hline Settling & $20 \mathrm{~min}$, settling using slime EPS and $\mathrm{CaCl}_{2}$ \\
\hline R-101 & Lipid extraction \\
\hline Agitation-I & $20 \mathrm{~min}$, Treatment by free-nitrous acid under agitation \\
\hline Agitation-II & 20 min, Treatment by N-LS under agitation \\
\hline Lipid recovery & $\begin{array}{l}20 \mathrm{~min} \text {, Lipid recovery using petroleum diesel under heating } \\
\left(70^{\circ} \mathrm{C}\right)\end{array}$ \\
\hline OS-101 & Phase separation I \\
\hline Phase Separation & $60 \mathrm{~min}$, Separation of PD-lipid mixture from the cellular debris \\
\hline R-102 & Trans-esterification \\
\hline $\begin{array}{l}\text { Trans- } \\
\text { esterification }\end{array}$ & $60 \mathrm{~min}$, Production of FAME and crude glycerol \\
\hline OS-102 & Phase separation II \\
\hline Phase Separation & $\begin{array}{l}60 \text { min, Separation of B10 blended biodiesel from the crude } \\
\text { glycerol }\end{array}$ \\
\hline
\end{tabular}


most common and efficient technique for biomass harvesting, but the energy consumption and capital cost associated are unappealing. Dassey and Theegala (2013) reported cost of centrifugation to be $\$ 0.86 / \mathrm{kg}$ biomass, which is high. Flocculation is a well-established approach with a maximum harvesting efficiency of above $95 \%$, and it has been extensively studied in wastewater treatment systems, but the data on techno-economic analysis are scanty and the bio-flocculation process has not been applied to lipid bearing yeast cells for their separation (Yellapu et al., 2018).

2.1.3.1. Biomass settling using bio-flocculant A novel method of biomass settling (harvesting) has been developed in INRS lab using chemical and bio-flocculants (Yellapu et al., 2019b). Biomass settling was performed using bio-flocculant, EPS and chemical coagulant, calcium chloride $\left(\mathrm{CaCl}_{2}\right)$. Positively charged calcium ions (from coagulant) interact with negatively charged yeast cell wall. EPS contains a relatively large number of hydroxyl (-OH) and carboxyl (-COO-) groups (Nouha et al., 2016; Ram et al., 2018; Salim et al., 2012; Yu et al., 2009). The presence of these groups is favorable for the flocculation process to provide the surface charges, which helps in further binding with suspended particles and causes floc formation (Nouha et al., 2018). Settling of biomass obtained from sludge fermented broth was performed in a clarifier using $52 \mathrm{mM}$ calcium chloride followed by doses of slime EPS, S-EPS (39.9 mg/g biomass) (Yellapu et al., 2019b). The concentration of EPS and calcium chloride used for biomass settling is dependent on the biomass concentration (more than $40 \mathrm{~g} / \mathrm{L}$ biomass) obtained in sludge fermented broth. In the lab scale experiments, $166 \mathrm{~g} / \mathrm{L}$ settled biomass was attained in $5 \mathrm{~min}$ using $1000 \mathrm{~mL}$ measuring cylinder. Based on the settling velocity of $7.5 \mathrm{~cm} / \mathrm{min}$ in lab-scale experiments, settling time for $1.33 \mathrm{~m}$ high clarifier (working volume of $3.4 \times 10^{5} \mathrm{~L}$ with a design capacity of $5.08 \times 10^{5} \mathrm{~L}$ ) has been calculated to be $17.84 \mathrm{~min}$. Settling time of $20 \mathrm{~min}$ has been considered for cost simulations.

\subsubsection{Lipid extraction and recovery}

Several studies have been reported in the literature for lipid extraction. Enzyme based cell wall disruption is a very efficient method to enhance lipid extraction yield (Kim et al., 2013). Although enzymatic hydrolysis is a scalable approach, its economic viability due to the high cost of enzymes impedes the implementation in biodiesel production (Kim et al., 2013). Mechanical cell wall disruption such as bead milling and ultrasonication are very effective for cell wall disruption, but these are energy consuming processes (Yellapu et al., 2018). The cost of microbial oil extraction using the mechanical cell wall disruption process is very high, which is $\$ 3.40 / \mathrm{kg}$ oil (Koutinas et al. (2014). The other oil extraction methods such as solvent oil extraction, pressurized solvent extraction are efficient but expensive. Further, these techniques will cause solvent contamination in oil and may create problems of health hazards and environment pollution (Dong et al., 2016).

A novel method of lipid extraction was tested in INRS lab using bio-surfactant and free-nitrous acid (FNA), which would eliminate the requirement of organic solvents and energy intensive bead milling (Yellapu et al., 2019b). The settled sludge biomass (166g/L) with the aid of EPS was treated with FNA and surfactant, N-LS (Yellapu et al., $2019 \mathrm{~b})$. FNA and its derivatives such as nitric oxide $\left(\mathrm{NO}_{3}\right)$ and nitrous anhydride $\left(\mathrm{N}_{2} \mathrm{O}_{3}\right)$ are effective for degradation of proteins and polysaccharides suggesting that FNA can disrupt the cell wall (Wu et al., 2018). The surfactant, N-LS disrupts the cell membrane and form mixed micelles containing the surfactant, proteins and lipids (le Maire et al., 2000). The mechanism of permeabilization also depends on the interaction of the detergents with proteins and the lipids of the cell membrane, which results in pore formation in the membrane or perturbation of the membrane structure (Vasileva-Tonkova et al., 2001). The settled sludge biomass $(166 \mathrm{~g} / \mathrm{L})$ was treated with FNA (10 mg FNA/ $\mathrm{g}$ biomass) for 20 min followed by treatment with surfactant, $\mathrm{N}$-lauryl sarcosine (20 mg N-LS/ g biomass) for $20 \mathrm{~min}$ (Yellapu et al., 2019b).

After cell disruption, the released lipid was recovered using PD (10.64 L PD $/ \mathrm{kg}$ lipid) at $70^{\circ} \mathrm{C}$ for $20 \mathrm{~min}$ (Yellapu et al., 2019b). Petroleum diesel is a non-polar solvent with a high boiling point and has lower cost as compared to organic solvents like chloroform and methanol (Yellapu et al., 2019a) and does not require recovery because PD will be used as fuel. The lipid extraction efficiency was $95 \%$ as reported by Yellapu et al. (2019b). The resulting solution was sent to a phase separation tank $\left(1.6 \times 10^{5} \mathrm{~L}\right.$ design capacity with $1.32 \times 10^{5} \mathrm{~L}$ working volume), which was assumed to operate for $60 \mathrm{~min}$ at $99 \%$ efficiency. Petroleum diesel containing microbial oil separates out from the cellular debris in the oil separation tank as the top layer while cellular debris along with water form as bottom layer. For 1 batch, $6410 \mathrm{~L} \mathrm{mi-}$ crobial lipid is recovered along with PD (58 $737 \mathrm{~L})$. One percent loss of PD has been assumed during lipid recovery and subsequent steps. Petroleum diesel containing microbial lipids was directed to the trans-esterification process.

\subsubsection{Trans-esterification}

Microbial lipids dissolved in petroleum diesel (6410 L lipid in 58,737 L PD) were reacted with methanol ( $6 \mathrm{~mol}$ methanol/ mole lipid) to produce biodiesel in the presence of $1 \%$ (w/v lipid) acid catalyst (sulphuric acid). The trans-esterification reaction was carried out in a chemical reactor (75 $421 \mathrm{~L}$ working volume with $90000 \mathrm{~L}$ design capacity) at $60^{\circ} \mathrm{C}$ for one hour and trans-esterification efficiency was 97\% (Yellapu et al., $2019 b)$. The reaction scheme is presented in Eq. (1).

891.5glipid + 96.12gmethanol

$\rightarrow$ 864.75gFAME +122.87 gglycerol

After transesterification, mixture was sent to a phase separation tank where the FAMEs (biodiesel) were transferred to petroleum diesel (upper phase) while polar molecules like glycerol and residual catalyst $\left(\mathrm{H}_{2} \mathrm{SO}_{4}\right)$ form a separate hydrophilic phase (bottom phase). The phase separation tank (75 $421 \mathrm{~L}$ working volume with $90000 \mathrm{~L}$ design capacity) operated with a settling efficiency of $98 \%$. The final composition of the blended product stream was 9.97\% FAME and 90.03\% petrol-diesel. Although traces of metals, catalyst and glycerol are obtained in biodiesel phase, purification studies of crude biodiesel are currently ongoing in INRS laboratory.

\subsection{Description of conventional process}

INRS process needs to be compared with conventional process for biodiesel production. Following is the description of the conventional process. For microbial lipid production using fermentation, the assumptions were taken according to the study of Koutinas et al. (2014). The lipid fermentation occurred in $134 \mathrm{~h}$ while $106.50 \mathrm{~g} / \mathrm{L}$ total biomass and $71.90 \mathrm{~g} / \mathrm{L}$ lipid were produced using Rhodosporidium toruloides. The carbon source used in the fermentation was glucose $(304 \mathrm{~g} / \mathrm{L})$ while yeast extract $(15.70 \mathrm{~g} / \mathrm{L})$ and peptone $(15.70 \mathrm{~g} / \mathrm{L})$ were used as nutrient and nitrogen source to produce $106.50 \mathrm{~g} / \mathrm{L}$ total biomass and $71.90 \mathrm{~g} /$ L lipid (Koutinas et al., 2014). Media was sterilized at $121^{\circ} \mathrm{C}$ for $15 \mathrm{~min}$ before the fermentation, and $10 \%(\mathrm{v} / \mathrm{v})$ inoculum was considered in the calculations. Fermentation was followed by centrifugation (biomass harvesting) and biomass drying. The cell wall disruption was achieved by conventional process employing a solvent mixture of chloroform-methanol ( $5 \mathrm{~mL}$ mixture $/ \mathrm{g}$ biomass) at $60^{\circ} \mathrm{C}(2: 1 \mathrm{v} / \mathrm{v})$ for $4 \mathrm{~h}$ (Yellapu et al., 2016; Yellapu et al., 2017). Thereafter, lipid-solvent mixture was separated from cellular debris by centrifugation and the solvent mixture was simply evaporated and recovered for the next cycle. The extracted lipids (after solvent evaporation) were mixed in a reactor with methanol (6:1 $\mathrm{M}$ ratio of methanol to oil) and $1 \%(\mathrm{w} /$ 
w of lipid) $\mathrm{NaOH}$ as the catalyst for 30 min trans-esterification reaction (Yellapu et al., 2017). The lipid extraction and trans-esterification efficiency were considered as $98 \%$ and $97 \%$, respectively (Yellapu et al., 2017). Further, FAMEs (biodiesel) need to be blended with petroleum diesel according to government regulations to give Blended biodiesel B10 product. Process flow diagram for INRS process and conventional process have been indicated by Figs. 1 and 2, respectively. In the conventional process for microbial oil and biodiesel production, 6 steps were involved to get blended biodiesel while in INRS process, only 4 steps are involved in blended biodiesel product.

\subsection{Simulation description and assumptions}

In this study, using SuperPro designer (v10), two processes (INRS and conventional) were simulated to produce blended biodiesel (B-10) using microbial lipids. The simulations were performed to produce 20 million L of blended biodiesel (B-10) to meet annual biodiesel demand for Quebec province, Canada. The plant was assumed to operate continuously for 350 days per year and was assumed to be built near the municipal wastewater treatment plant. Hence, sludge transportation costs have not been considered in the INRS process.

\subsection{Mass and energy balance}

Mass and Energy balance was calculated based on per tonne of FAMEs produced from each of the processes. The calculation started with raw materials and ends until the blended biodiesel was obtained. The electricity, steam or heating used in the process was considered direct energy, which means that energy contents of these items are used in the calculation, while other materials (chemicals, solvents, etc.) used during the production were considered indirect energy in which energy consumed during the production of these materials was used in the cal- culation (Kumar et al., 2019b). Following are the important energy terms used during making energy balance calculations:

Energy input: Sum of all energy inputs at every process step

Energy credit: Internal energy present in co-products

Net energy input: The difference between energy input and energy credit

Energy balance: Energy contained in produced biodiesel after subtracting the net energy input

Energy ratio: The ratio between energy output and net energy input

For an energetically favourable process, net energy balance across the complete process should be positive or energy ratio (output/input) should be greater than 1 .

\subsection{Economic evaluation}

The annual operational cost was calculated using all the significant components of production like raw material cost, labour cost, laboratory quality control (QC), waste disposal cost and utilities cost into account. Revenues production rates were obtained by the rigorous mass balance across the process and were multiplied with a unit price of the commodities available in the market to get annual revenues and credits (Kumar et al., 2019c).

\subsection{Revenue and profitability analysis}

To evaluate the profitability of the process gross margin, return on investment (ROI), gross profit and payback time was calculated according to following scheme (Eqs. (2), (3), (4), (5)).

$\begin{aligned} \text { GrossProfit }= & \text { Revenue }(s)-\text { Annualoperatingcost } \\ & - \text { Depreciation }\end{aligned}$

Netprofit $=$ Grossprofit - Taxespaidbythecompany
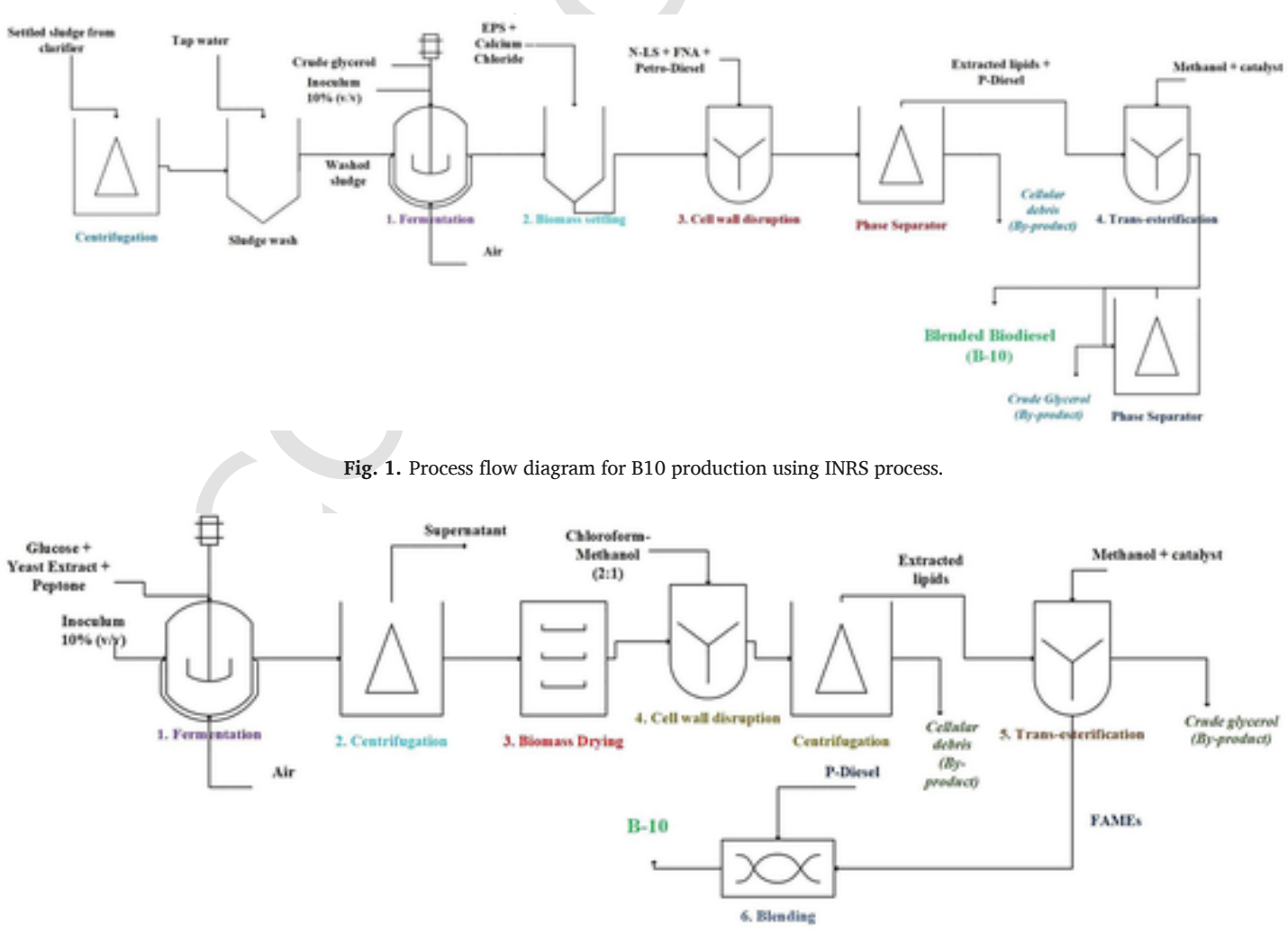

Fig. 2. Process flow diagram for B10 production using conventional process. 


$$
\begin{aligned}
& R O I(\%)=\frac{\text { Netprofit }}{\text { TotalInvestment }} * 100 \\
& \text { Paybacktime(years) }=\frac{\text { TotalInvestmet }}{\text { Netprofit }}
\end{aligned}
$$

\section{Results and discussion}

\subsection{Mass and energy balance}

\subsubsection{INRS process}

Mass and energy balance has been performed to produce 1 tonne FAMEs or 10 tonnes blended biodiesel B10 using the INRS process with microbial oil produced from sludge fortified with crude glycerol (Table $2 \mathrm{a})$. It was assumed that the fermentation would take place near a waste treatment plant; thus, there was no energy input in sludge transportation. No energy input has been assumed for sludge as it is considered a waste and normally energy is imparted for its treatment. Crude glycerol is a by-product of the biodiesel production process and requires substantial efforts and energy input to purify it. Crude glycerol, produced during the trans-esterification process can be fortified with washed sludge for lipid production. Hence, the energy input from the utilization of crude glycerol was not considered and the crude glycerol generated in the process of trans-esterification was also given an energy value of zero. The mass of chemicals required for the biodiesel production was in the column 'amount supplied'. The energy input from chemical addition to process was the energy consumed to produce the amount of chemicals (Chen et al., 2018b; Zhang et al., 2017; Zhang et al., 2016). The energy imparted during the agitation and mixing were also taken from the literature (Zhang et al., 2019). The sludge was concentrated using centrifugation $\left(1 \mathrm{kWh} / \mathrm{m}^{3}\right)$ to obtain desired solids concentration of 35 $\mathrm{g} / \mathrm{L}$ and washed with tap water (30 L/kg sludge solids). Sludge washing will be performed in a clarifier where tap water will be added to the concentrated sludge and sludge was allowed to settle after agitation $\left(7.30 \mathrm{~W} / \mathrm{m}^{3}\right)$. The total energy input in sludge washing and concentration step was $0.92 \mathrm{GJ} /$ tonne B10 where centrifugation was the major energy imparting factor. The total energy input in the production fermenter was $16.39 \mathrm{GJ} /$ tonne B10 biodiesel using sludge fortified with crude glycerol as a carbon source. Out of which aeration $(0.5 \mathrm{vvm})$ and sodium hydroxide used for sludge pre-treatment were major contributing factors. The seed fermentation energy input was calculated to be 1.64 GJ (10\% of production fermenter). The total energy during biomass settling was calculated to be $4.29 \mathrm{GJ}$ where the energy content of EPS and calcium chloride were the contributing factors. For PD used during lipid recovery, $1 \%$ loss $(0.01 \times 9000=90 \mathrm{~kg})$ in PD during lipid recovery and subsequent steps were considered. This loss was taken as an energy input (Table 2a). The remaining (99\%) diesel used during lipid recovery remained as fuel in the blended biodiesel (B10). During the lipid extraction process, the total energy input was $4.50 \mathrm{GJ} /$ tonne biodiesel where loss of PD during lipid recovery was a major contributing factor. During the trans-esterification process, the energy input was $7 \mathrm{GJ} /$ tonne B10 biodiesel where methanol was a major contributing factor. The main contributing step in INRS process was lipid production in fermentation (47.16\%) followed by trans-esterification (20.18\%) and lipid extraction (12.94\%). For the INRS process, net energy input was 34.75 $\mathrm{GJ} /$ tonne B10 while energy output was $37.80 \mathrm{GJ} /$ tonne B10 with a net energy gain (energy output - energy input) of $3.05 \mathrm{GJ} /$ tonne B10 and energy ratio (energy output/ energy input) of 1.09 making the process energetically favorable.

\subsubsection{Conventional process}

Mass balance and energy balance have been performed for producing 1 tonne of FAMEs or 10 tonnes blended biodiesel B10 using con-
Table 2a

Mass and Energy balance of B-10 production process using INRS process (10-tonne

\begin{tabular}{|c|c|c|c|c|c|}
\hline Step & Items & $\begin{array}{l}\text { Unit } \\
\text { energy }\end{array}$ & $\begin{array}{l}\text { Amount } \\
\text { supplied }\end{array}$ & $\begin{array}{l}\text { Energy } \\
\text { input } \\
\text { (MJ) }\end{array}$ & $\begin{array}{l}\text { Energy } \\
\text { input } \\
(\%)\end{array}$ \\
\hline \multirow[t]{4}{*}{$\begin{array}{l}\text { Sludge } \\
\text { Concentration }\end{array}$} & $\begin{array}{l}\text { Centrifugation } \\
\left(\mathrm{kWh} / \mathrm{m}^{3}\right)\end{array}$ & 1.0 & 225.75 & 813 & 2.34 \\
\hline & $\begin{array}{l}\text { Tap water } \\
\left(\mathrm{MJ} / \mathrm{m}^{3}\right) \text { for } \\
\text { washing }\end{array}$ & 0.04 & 67.7 & 3 & 0.01 \\
\hline & $\begin{array}{l}\text { Agitation (W/ } \\
\mathrm{m}^{3} \text { ) }\end{array}$ & & 85.8 & 108 & 0.31 \\
\hline & $\begin{array}{l}\text { Energy input it } \\
\text { and wash (MJ) }\end{array}$ & udge cor & ntration & 924 & 2.66 \\
\hline \multirow{7}{*}{$\begin{array}{l}\text { Production } \\
\text { Fermentation }\end{array}$} & Working volun & & $64.5 \mathrm{~m}^{3}$ & & \\
\hline & $\begin{array}{l}\text { Sterilization } \\
(\mathrm{MJ} / \mathrm{kg})\end{array}$ & 26.00 & $7.10 \mathrm{~kg}$ & 184 & 0.53 \\
\hline & $\begin{array}{l}\mathrm{NaOH}(\mathrm{MJ} / \\
\mathrm{kg})\end{array}$ & 18.50 & $186 \mathrm{~kg}$ & 3441 & 9.9 \\
\hline & $\begin{array}{l}\mathrm{H}_{2} \mathrm{SO}_{4}(\mathrm{MJ} / \\
\mathrm{kg})\end{array}$ & 7.10 & $216 \mathrm{~kg}$ & 1534 & 4.41 \\
\hline & $\begin{array}{l}\text { Agitation (W/ } \\
\mathrm{m}^{3} \text { ) }\end{array}$ & 7.30 & $64.50 \mathrm{~m}^{3}$ & 81 & 0.23 \\
\hline & $\begin{array}{l}\text { Aeration } \\
\left(\mathrm{kW} / \mathrm{m}^{3}\right)\end{array}$ & 1.00 & $64.50 \mathrm{~m}^{3}$ & 11146 & 32.08 \\
\hline & \multicolumn{3}{|c|}{ Energy input in Lipid Production (MJ) } & 16386 & 47.16 \\
\hline $\begin{array}{l}\text { Seed } \\
\text { Fermentation }\end{array}$ & \multicolumn{3}{|c|}{$10 \%$ of Production fermenter (MJ) } & 1639 & 4.72 \\
\hline \multirow[t]{3}{*}{ Biomass settling } & EPS $(\mathrm{MJ} / \mathrm{kg})$ & 14.36 & $114.76 \mathrm{~kg}$ & 1648 & 4.74 \\
\hline & $\begin{array}{l}\mathrm{CaCl}_{2}(\mathrm{MJ} / \\
\mathrm{kg})\end{array}$ & 7.20 & $367 \mathrm{~kg}$ & 2642 & 7.6 \\
\hline & \multicolumn{3}{|c|}{ Energy Input in Biomass Settling (MJ) } & 4290 & 12.35 \\
\hline \multirow[t]{7}{*}{ Lipid extraction } & \multicolumn{2}{|c|}{ Working volume } & $12.32 \mathrm{~m}^{3}$ & & \\
\hline & $\mathrm{N}-\mathrm{LS}(\mathrm{MJ} / \mathrm{kg})$ & 5.76 & $57.38 \mathrm{~kg}$ & 331 & 0.95 \\
\hline & FNA $(\mathrm{MJ} / \mathrm{kg})$ & 3.20 & $26.69 \mathrm{~kg}$ & 85 & 0.25 \\
\hline & $\begin{array}{l}\text { Agitation (W/ } \\
\mathrm{m}^{3} \text { ) }\end{array}$ & 7.3 & $12.32 \mathrm{~m}^{3}$ & 0.23 & 0.00 \\
\hline & $\begin{array}{l}\text { Heating (kW/ } \\
\mathrm{m}^{3} \text { ) }\end{array}$ & 2.72 & $12.32 \mathrm{~m}^{3}$ & 30 & 0.09 \\
\hline & $\begin{array}{l}\text { Loss in PD } \\
(\mathrm{MJ} / \mathrm{kg})\end{array}$ & 45 & $90 \mathrm{~kg}$ & 4050 & 11.66 \\
\hline & \multicolumn{3}{|c|}{ Energy input in Lipid extraction (MJ) } & 4496 & 12.94 \\
\hline \multirow[t]{5}{*}{$\begin{array}{l}\text { Trans- } \\
\text { esterification }\end{array}$} & $\begin{array}{l}\text { Methanol } \\
(\mathrm{MJ} / \mathrm{kg})\end{array}$ & 20.00 & $326.5 \mathrm{~kg}$ & 6530 & 18.79 \\
\hline & $\begin{array}{l}\text { Sulphuric acid } \\
(\mathrm{MJ} / \mathrm{kg})\end{array}$ & 7.10 & $19 \mathrm{~kg}$ & 135 & 0.39 \\
\hline & $\begin{array}{l}\text { Mixing (kWh/ } \\
\text { kg biodiesel) }\end{array}$ & 0.03 & $1000 \mathrm{~kg}$ & 108 & 0.31 \\
\hline & $\begin{array}{l}\text { Heating (kJ/ } \\
\text { kg biodiesel) }\end{array}$ & 240.00 & $1000 \mathrm{~kg}$ & 240 & 0.69 \\
\hline & $\begin{array}{l}\text { Energy Input i } \\
(\mathrm{MJ})\end{array}$ & rans-este & cation & 7013 & 20.18 \\
\hline \multicolumn{4}{|c|}{ Net Energy input (GJ) } & 34.75 & \\
\hline \multicolumn{4}{|c|}{ Net Energy output (GJ) } & 37.80 & \\
\hline \multicolumn{4}{|c|}{ Net Energy gain (GJ) } & 3.05 & \\
\hline \multicolumn{4}{|c|}{ Energy ratio (Energy output/ energy input) } & 1.09 & \\
\hline
\end{tabular}
blended biodiesel B10).

ventional process (Table $2 \mathrm{~b}$ ). The mass of chemicals required for the biodiesel production was in the column 'Amount supplied'. The total energy input for fermentation (production fermenter) was $30.68 \mathrm{GJ} /$ tonne B10 biodiesel (Table 2b). Out of which, glucose used as the carbon source was a major energy contributing factor $(60 \%$ of fermentation step) followed by aeration $(0.5 \mathrm{vvm})$ that was dependent on the time of fermentation ( $134 \mathrm{~h}$ in this case). The seed fermentation energy input was considered $10 \%$ energy input of production fermenter as $10 \%(\mathrm{v} / \mathrm{v})$ inoculum size was considered. The energy input in centrifu- 
Table $2 b$

Mass and Energy balance of B-10 production process using conventional process (10-tonne blended biodiesel B10).

\begin{tabular}{|c|c|c|c|c|c|}
\hline Step & Items & $\begin{array}{l}\text { Unit } \\
\text { energy }\end{array}$ & $\begin{array}{l}\text { Amount } \\
\text { supplied }\end{array}$ & $\begin{array}{l}\text { Energy } \\
\text { input } \\
(\mathrm{MJ})\end{array}$ & $\begin{array}{l}\text { Energy } \\
\text { input } \\
(\%)\end{array}$ \\
\hline \multirow{8}{*}{$\begin{array}{l}\text { Production } \\
\text { Fermentation }\end{array}$} & \multicolumn{2}{|l|}{ Working volume } & \multicolumn{2}{|l|}{$14.34 \mathrm{~m}^{3}$} & \\
\hline & $\begin{array}{l}\text { Sterilization } \\
(\mathrm{MJ} / \mathrm{kg})\end{array}$ & 26.00 & $1.58 \mathrm{~kg}$ & 41 & 0.03 \\
\hline & $\begin{array}{l}\text { Yeast extract } \\
(\mathrm{MJ} / \mathrm{kg})\end{array}$ & 6.46 & $225 \mathrm{~kg}$ & 1453 & 1.03 \\
\hline & $\begin{array}{l}\text { Peptone (MJ/ } \\
\mathrm{kg} \text { ) }\end{array}$ & 17.30 & $225 \mathrm{~kg}$ & 3893 & 2.77 \\
\hline & $\begin{array}{l}\text { Glucose (MJ/ } \\
\mathrm{kg} \text { ) }\end{array}$ & 4.20 & $4363 \mathrm{~kg}$ & 18325 & 13.03 \\
\hline & $\begin{array}{l}\text { Agitation (W/ } \\
\mathrm{m}^{3} \text { ) }\end{array}$ & 7.30 & $14.34 \mathrm{~m}^{3}$ & 51 & 0.04 \\
\hline & $\begin{array}{l}\text { Aeration } \\
\left(\mathrm{kW} / \mathrm{m}^{3}\right)\end{array}$ & 1.00 & $14.34 \mathrm{~m}^{3}$ & 6918 & 4.92 \\
\hline & \multicolumn{3}{|c|}{ Energy input in Lipid Production (MJ) } & 30,681 & 21.82 \\
\hline Seed & \multicolumn{3}{|c|}{$10 \%$ of Production fermenter (MJ) } & 3068 & 2.18 \\
\hline \multicolumn{6}{|l|}{ Fermentation } \\
\hline \multirow[t]{2}{*}{$\begin{array}{l}\text { Biomass } \\
\text { Harvesting }\end{array}$} & $\begin{array}{l}\text { Centrifugation } \\
\left(\mathrm{kWh} / \mathrm{m}^{3}\right)\end{array}$ & 1.00 & $14.34 \mathrm{~m}^{3}$ & 52 & 0.04 \\
\hline & \multicolumn{3}{|c|}{ Energy Input in Biomass Harvesting (MJ) } & 52 & 0.04 \\
\hline \multirow[t]{3}{*}{ Biomass Drying } & $\begin{array}{l}\text { Drying (kWh/ } \\
\text { tonne) }\end{array}$ & 134 & 1.5 tonne & 201 & 0.14 \\
\hline & $\begin{array}{l}\text { Grinding } \\
\text { (kWh/ tonne) }\end{array}$ & 16 & 1.5 tonne & 86 & 0.06 \\
\hline & \multicolumn{3}{|c|}{ Energy input in Biomass Drying (MJ) } & 287 & 0.2 \\
\hline \multirow[t]{7}{*}{ Lipid extraction } & \multicolumn{2}{|c|}{ Reaction volume } & $7.63 \mathrm{~m}^{3}$ & & \\
\hline & $\begin{array}{l}\text { Chloroform } \\
\text { (MJ/kg) }\end{array}$ & 7.63 & $7577.56 \mathrm{~kg}$ & 57,817 & 41.12 \\
\hline & $\begin{array}{l}\text { Methanol } \\
(\mathrm{MJ} / \mathrm{kg})\end{array}$ & 20.00 & $2014.85 \mathrm{~kg}$ & 40,297 & 28.66 \\
\hline & $\begin{array}{l}\text { Solvent } \\
\text { recovery } \\
(\mathrm{kWh} / \mathrm{t})\end{array}$ & 19.50 & 9.6 tonne & 674 & 0.48 \\
\hline & $\begin{array}{l}\text { Heating (kW/ } \\
\mathrm{m}^{3} \text { ) }\end{array}$ & 2.72 & $7.63 \mathrm{~m}^{3}$ & 299 & 0.21 \\
\hline & $\begin{array}{l}\text { Centrifugation } \\
\left(\mathrm{kWh} / \mathrm{m}^{3}\right)\end{array}$ & 1.00 & $7.63 \mathrm{~m}^{3}$ & 27 & 0.02 \\
\hline & \multicolumn{3}{|c|}{ Energy input in Lipid extraction (MJ) } & 99,114 & 70.5 \\
\hline \multirow[t]{5}{*}{$\begin{array}{l}\text { Trans- } \\
\text { esterification }\end{array}$} & $\begin{array}{l}\text { Methanol } \\
(\mathrm{MJ} / \mathrm{kg})\end{array}$ & 20.00 & $326.63 \mathrm{~kg}$ & 6533 & 4.64 \\
\hline & $\begin{array}{l}\mathrm{NaOH}(\mathrm{MJ} / \\
\mathrm{kg})\end{array}$ & 18.50 & $21.96 \mathrm{~kg}$ & 407 & 0.29 \\
\hline & $\begin{array}{l}\text { Mixing (kWh/ } \\
\text { kg FAME) }\end{array}$ & 0.03 & $1000 \mathrm{~kg}$ & 108 & 0.08 \\
\hline & $\begin{array}{l}\text { Heating (kJ/ } \\
\text { kg FAME) }\end{array}$ & 240.00 & $1000 \mathrm{~kg}$ & 240 & 0.17 \\
\hline & \multicolumn{3}{|c|}{ Energy Input in Trans-esterification (MJ) } & 7288 & 5.18 \\
\hline \multirow[t]{2}{*}{ Blending } & $\begin{array}{l}\text { Mixing (kWh/ } \\
\text { kg biodiesel) }\end{array}$ & 0.03 & $1000 \mathrm{~kg}$ & 108 & 0.08 \\
\hline & \multicolumn{3}{|c|}{ Energy Input in Blending (MJ) } & 108 & 0.08 \\
\hline \multicolumn{4}{|c|}{ Total energy input (GJ) } & 140.60 & \\
\hline \multicolumn{4}{|c|}{ Credits - crude glycerol (GJ) } & 3.85 & \\
\hline \multicolumn{4}{|c|}{ Net energy input (GJ) } & 136.75 & \\
\hline \multicolumn{4}{|c|}{ Net Energy output (GJ) } & 37.80 & \\
\hline \multicolumn{4}{|c|}{ Net Energy gain (GJ) } & -98.95 & \\
\hline \multicolumn{4}{|c|}{ Energy ratio (Energy output/ energy input) } & 0.28 & \\
\hline
\end{tabular}

gation and drying steps were $51.62 \mathrm{MJ}$ and $287.40 \mathrm{MJ}$ per tonne B10 biodiesel, respectively. The total energy input at lipid extraction step was $99.11 \mathrm{GJ} /$ tonne B10 biodiesel. Out of which, chloroform and methanol used for lipid extraction were major energy contributing steps (99\% of lipid extraction step). During trans-esterification, methanol used was a major contributing factor and total energy in- put at trans-esterification step was $7.29 \mathrm{GJ} /$ tonne B10 biodiesel. The crude biodiesel was blended to get B-10 biodiesel. The energy input during blending $(0.03 \mathrm{kWh} / \mathrm{kg}$ biodiesel) was considered from Zhang et al. (2017). The energy input at blending step was $108 \mathrm{MJ} /$ tonne B10 biodiesel. During the blending, the energy imparted by mixing was only considered. Petroleum-diesel was directly used during blending without any energy input. Hence, the energy input from the utilization of PD was assumed to be zero and the energy imparted from PD in blended biodiesel has also been considered zero. For the conventional biodiesel production process using microbial oil, net energy gain of the process was calculated to be $-98.95 \mathrm{GJ} /$ tonne B10 and energy ratio of 0.28 , making it energetically unfavorable. For the conventional process, lipid extraction step contributed to $70.50 \%$ of total energy input where solvents used, chloroform and methanol were major energy contributing factors. The INRS process saved total energy of $102 \mathrm{GJ} /$ tonne B10 when compared to the conventional process. Major energy savings occurred in the lipid extraction step and the fermentation step.

\subsection{Economic evaluation of INRS process}

\subsubsection{Equipment sizing}

Equipment sizing and purchase cost have been highlighted in Table 3a. Stainless steel grade 304 (SS304) was chosen as the material of construction for the reactors, vessels and fermenters. SS304, with its chromium-nickel content and low carbon, is the most versatile and widely used type of stainless steel. It contains $18 \%$ chromium and $8 \%$ nickel. SS304 is resistant to oxidation, corrosion, and durable (Phadnis et al., 2003) for this type of application. All the fermenters and vessels had height to diameter ratio (H/D) of 3 and were built at design pressure of 1.5 bar. The clarifiers (for sludge settling and biomass settling) and phase separation tanks were made of carbon steel (CS) as they were only used for settling and phase separation. The clarifier used for sludge settling (CLR-102) has working capacity of $2.29 \times 10^{6} \mathrm{~L}$ while it has a design capacity of $3 \times 10^{6} \mathrm{~L}$ (diameter $30 \mathrm{~m}$ and height $4.25 \mathrm{~m}$ ). The same clarifier will be used during the sludge washing. One bowl centrifuge (BC-101) has been considered for obtaining a desired sludge solids concentration. For one batch, $1.15 \times 10^{5} \mathrm{~L}$ of settled sludge (obtained after settling in a clarifier) needs to be centrifuged to concentrate the sludge to $35 \mathrm{~g} / \mathrm{L}$. The centrifugation was performed at $5000 \mathrm{~g}$ for $9 \mathrm{~h}$ with the processing rate of $12.77 \mathrm{~m}^{3} / \mathrm{h}$.

\subsubsection{Equipment purchase cost (EPC)}

The equipment purchase cost was estimated in US\$. The assumed prices for the equipment were derived from studies and quotations provided by different manufacturers. The total equipment purchase cost has been divided into various sub-sections - process equipment, cleaning-in-place (CIP) generation system, water purification system and distributed control system (DCS). Total equipment purchase costs were estimated to be 15.68 million $\$$. Process equipment contributes to $92.93 \%$ of total equipment purchase costs. Among the process equipment, two production fermenters contribute most $(70.40 \%$ of EPC) followed by five seed fermenters for inoculum development (12.1\% of EPC). Sludge concentration equipment (a clarifier and a bowl centrifuge) contributes $5.77 \%$ of EPC followed by lipid extraction equipment (5.68\% of EPC) and trans-esterification equipment (3.76\% of EPC). CIP generation system with a tank, skid, transfer pump, heating element and a PLC (programmable logic controller) to $1.04 \%$ of total equipment purchase cost. The plant would be operated through complete automation with a DCS (control system with software, analog input/output and personal computer), which costs around 0.13 million dollars contributing $0.86 \%$ of total equipment purchase costs. For the plant operations, water purification unit has been considered. Water purification unit (using reverse osmosis) contributes to $0.64 \%$ of total equipment purchase costs. 
Table 3a

Distribution of equipment purchase cost for INRS process (Freight on Board).

Sludge settling

Production Fermenter

Biomass settling

Lipid extraction

Trans-esterification

Software \& DCS

CIP systems

\begin{tabular}{|c|c|c|c|c|c|}
\hline Equipment & $\begin{array}{l}\text { Equipment } \\
\text { Capacity }\end{array}$ & $\begin{array}{l}\text { Equipment } \\
\text { cost (\$) }\end{array}$ & $\begin{array}{l}\text { Number } \\
\text { of units }\end{array}$ & $\begin{array}{l}\text { Final } \\
\text { cost } \\
(\$)\end{array}$ & Cost $\%$ \\
\hline $\begin{array}{l}\text { Erlenmeyer } \\
\text { flask } \\
\text { (SFR-106) }\end{array}$ & $1 \mathrm{~L}$ & 50 & 1 & 50 & 0.00 \\
\hline $\begin{array}{l}\text { Seed } \\
\text { Fermenter } \\
\text { (SFR-105) }\end{array}$ & $5 \mathrm{~L}$ & 25000 & 1 & $\begin{array}{l}25 \\
000\end{array}$ & 0.16 \\
\hline $\begin{array}{l}\text { Seed } \\
\text { Fermenter } \\
\text { (SFR-104) }\end{array}$ & $50 \mathrm{~L}$ & 50000 & 1 & $\begin{array}{l}50 \\
000\end{array}$ & 0.32 \\
\hline $\begin{array}{l}\text { Seed } \\
\text { Fermenter } \\
\text { (SFR-103) }\end{array}$ & $500 \mathrm{~L}$ & 87469 & 1 & $\begin{array}{l}87 \\
469\end{array}$ & 0.56 \\
\hline $\begin{array}{l}\text { Seed } \\
\text { Fermenter } \\
\text { (SFR-102) }\end{array}$ & $5000 \mathrm{~L}$ & 348220 & 1 & $\begin{array}{l}348 \\
220\end{array}$ & 2.22 \\
\hline $\begin{array}{l}\text { Seed } \\
\text { Fermenter } \\
\text { (SFR-101) }\end{array}$ & $50000 \mathrm{~L}$ & 1386290 & 1 & $\begin{array}{l}1386 \\
290\end{array}$ & 8.84 \\
\hline $\begin{array}{l}\text { Clarifier for } \\
\text { sludge } \\
\text { settling and } \\
\text { washing } \\
\text { (CLR-102) }\end{array}$ & $\begin{array}{l}3000000 \\
\mathrm{~L}\end{array}$ & 120000 & 1 & $\begin{array}{l}120 \\
000\end{array}$ & 0.77 \\
\hline $\begin{array}{l}\text { Bowl } \\
\text { Centrifuge } \\
\text { (BC-101) }\end{array}$ & $15 \mathrm{~m}^{3} / \mathrm{h}$ & 784008 & 1 & $\begin{array}{l}784 \\
008\end{array}$ & 5.00 \\
\hline $\begin{array}{l}\text { Production } \\
\text { fermenter } \\
\text { (FR-101) }\end{array}$ & $500000 \mathrm{~L}$ & 5518919 & 2 & $\begin{array}{l}11 \\
037 \\
837\end{array}$ & 70.40 \\
\hline $\begin{array}{l}\text { Clarifier for } \\
\text { fermented } \\
\text { broth } \\
\text { (CLR-101) }\end{array}$ & $508680 \mathrm{~L}$ & 35000 & 1 & $\begin{array}{l}35 \\
000\end{array}$ & 0.22 \\
\hline $\begin{array}{l}\text { Lipid } \\
\text { extraction } \\
\text { reactor } \\
\text { (R-101) }\end{array}$ & $160000 \mathrm{~L}$ & 870551 & 1 & $\begin{array}{l}870 \\
551\end{array}$ & 5.55 \\
\hline $\begin{array}{l}\text { Phase } \\
\text { separator I } \\
\text { (OS-101) }\end{array}$ & $160000 \mathrm{~L}$ & 20000 & 1 & $\begin{array}{l}20 \\
000\end{array}$ & 0.13 \\
\hline $\begin{array}{l}\text { Trans- } \\
\text { esterification } \\
\text { reactor } \\
\text { (R-102) }\end{array}$ & $90000 \mathrm{~L}$ & 574349 & 1 & $\begin{array}{l}574 \\
349\end{array}$ & 3.66 \\
\hline \multirow[t]{2}{*}{$\begin{array}{l}\text { Phase } \\
\text { separator II } \\
\text { (OS-102) }\end{array}$} & $90000 \mathrm{~L}$ & 15000 & 1 & $\begin{array}{l}15 \\
000\end{array}$ & 0.10 \\
\hline & & 135000 & 1 & $\begin{array}{l}135 \\
000\end{array}$ & 0.86 \\
\hline $\begin{array}{l}\text { CIP tank } \\
\text { including } \\
\text { pump \& PLC }\end{array}$ & & 160000 & 1 & $\begin{array}{l}160 \\
000\end{array}$ & 1.02 \\
\hline $\begin{array}{l}\text { CIP skid for } \\
\text { transfer }\end{array}$ & & 1400 & 1 & 1400 & 0.01 \\
\hline \multirow{3}{*}{$\begin{array}{l}\text { Heating } \\
\text { element }\end{array}$} & & 1800 & 2 & 3600 & 0.02 \\
\hline & & 580000 & 1 & $\begin{array}{l}100 \\
000\end{array}$ & 0.64 \\
\hline & & & & 15.68 & 100.00 \\
\hline
\end{tabular}

Total Equipment purchase cost (Million \$) posed of equipment purchase cost, equipment installation cost, their instrumentation, insulation, electrical connection, cost for building development, improvement of the yard and other auxiliary charges. In this process plant, typical scheme of calculations was used, which often are used as rule of thumb for such bioprocesses. The scheme of calculation of plant direct cost was taken from Chen et al. (2018a). There are other indirect cost factors, like engineering and construction, 
Table $3 b$

Direct fixed cost for INRS process (20 million L plant capacity).

\begin{tabular}{lll}
\hline \multicolumn{2}{l}{ Direct fixed Cost components } & Million \$ \\
\hline \multicolumn{2}{l}{ Total plant direct cost (TPDC) } & \\
Equipment Purchase Cost, PC & 15.68 \\
Equipment Installation & $30 \%$ of PC & 4.70 \\
Process Piping & $30 \%$ of PC & 4.70 \\
Instrumentation & $25 \%$ of PC & 3.92 \\
Insulation & $8 \%$ of PC & 1.25 \\
Electrical & $10 \%$ of PC & 1.57 \\
Building & $20 \%$ of PC & 3.14 \\
Yard Improvement & $10 \%$ of PC & 1.57 \\
Auxiliary Facilities & $25 \%$ of PC & 3.92 \\
TPDC & & 40.45 \\
b. Total plant indirect cost (TPIC) & \\
Engineering & $8 \%$ of TPDC & 3.24 \\
Construction & $10 \%$ of TPDC & 4.05 \\
TPIC & 7.28 \\
Total Plant COST (TPC = TPDC + TPIC) & 47.73 \\
c. Contractor fee \& contingency (CFC) & \\
Contractor's Fee & $8 \%$ of Total Plant Cost & 2.39 \\
Contingency & 15\% of Total Plant Cost & 7.16 \\
CFC & 9.55 \\
Direct fixed cost (DFC = CFC + TPC) & 57.28 \\
\hline
\end{tabular}

which should be accounted. The engineering cost required to properly engineer the plant for required production is separately accounted ( $8 \%$ of the total plant direct cost). Further construction of the whole facility requires other additional charges, which can be accounted under the head of construction cost. The contingency fee is also incorporated to account for variation in the cost-estimate, which was considered $15 \%$ of additional sum of indirect and direct plant cost. Direct Fixed Cost $(\mathrm{DFC})=\mathrm{TPDC}+$ Construction cost + Engineering cost + Contractor's fee + contingency. The DFC for the process was calculated to be 57.28 million dollars (Table $3 \mathrm{~b}$ ).

\subsubsection{Annual operating cost}

The annual operational cost was calculated using all the significant components of production, which include raw material cost, labour cost, quality control, waste treatment, facility dependent and utilities. The cost of different raw materials was taken from bulk price from the internet and fed into the software for calculating the annual requirement of raw material. The average salary of plant operators was considered from the database of the software. The cost of treating aqueous waste was taken from Ram et al. (2018) and fed into the software for calculating annual waste treatment costs. A total sum of 14.46 million dollars is required to annually run the facility. Annual operating cost analysis (Table $4 \mathrm{a}$ ) of the process reveals that $40 \%$ of the total annual operating cost is because of utilities. Raw materials and facility dependent cost account for $33.35 \%$ and $19.80 \%$, respectively (Table $4 a$ ).

Table 4a

Distribution of annual operating cost for INRS process (20 million L plant capacity).

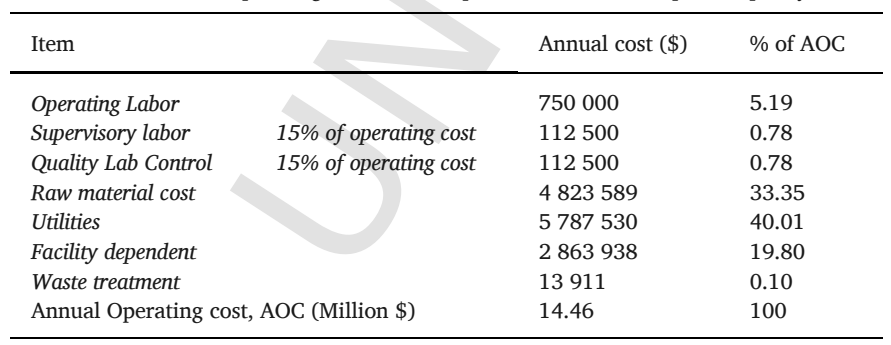

Annual expenditure for raw material purchase was 4.8 million $\$$. S-EPS $(0.95 \$ / \mathrm{L})$ used during biomass settling accounts for $60.32 \%$ of raw material cost. $\mathrm{NaOH}(1 \mathrm{M})$ used for cleaning of fermenters accounted for $14.05 \%$ of raw material cost. Municipal sludge, which was used as a principal carbon source as well as source of other nutrients, has no cost or zero cost as the facility was built near wastewater treatment plant

For all the heating and cooling requirements of the process various utilities like steam, brine solution and standard power are used in the process plant. A total sum of 5.80 million dollars is needed annually for utilities to run the plant. Standard electrical power and steam are most frequently used for heat generation and mechanical transport of materials. Brine solution ( $\$ 0.25 / \mathrm{MT}$, metric ton) is used for cooling of fermentation medium after sterilization and accounts for $42.32 \%$ of annual utility cost. Standard electricity $(\$ 0.10 / \mathrm{kW}-\mathrm{h})$ required for agitation during the fermentation, lipid extraction and trans-esterification account for $32.34 \%$ of annual utility cost while steam (\$12/ MT) used for sterilization of fermenters and heating during lipid extraction and trans-esterification account for $25.34 \%$ of annual utility cost. Since fermentation is the step where all three utilities are used, fermentation is major contributing factor in annual utility cost.

For operating labour, fifteen operators at average pay-scale of 50000 $\$$ per annum are required to operate the facility: 4 dedicated for seed fermenters, 4 dedicated for production fermenters, 2 dedicated for settling and lipid extraction, 1 dedicated for trans-esterification, 2 for warehouse and 2 for the accounts department. Operating labour cost was estimated to be 750000 \$. Supervision and QC labour has been considered 15\% each of annual operating labour cost. Since the plant has been considered fully automated, the number of operators is on the lower side.

Facility-dependent cost comprises of plant annual maintenance cost, insurances, local taxes and factory expenses. The maintenance cost is for proper running of the facility. This cost is $2 \%$ of DFC. Taxes are also imposed on the facility dependent cost. Insurance charges, local taxes and other factory expenses each are estimated as $1 \%$ of the DFC. The total facility dependent cost for this facility was calculated to be 2.86 million dollars. Since fermentation contributed $82.5 \%$ of the total equipment purchase cost, facility dependent cost is arising mainly from the repair and maintenance of fermenters.

For one batch, $411.90 \mathrm{~m}^{3}$ of aqueous waste is generated arising from CIP of fermenters and supernatant (obtained after biomass settling). Annually $1.26 \times 10^{5} \mathrm{~m}^{3}$ of aqueous waste is generated by the process plant, which is disposed at the rate of $\$ 0.11 / \mathrm{m}^{3}$.

\subsubsection{Unit production cost}

Through annual operating cost and quantity of B-10 produced annually, the unit production cost calculated was $\$ 0.72 / \mathrm{L}$ (Table $4 \mathrm{~b}$ ). However, two additional streams are produced during the production process: crude glycerol and cellular debris. The debris includes structural components of cell mass including proteins, carbohydrates, humic substances due to which it can be sold as animal feed supplement (Ram et al., 2018). Annually, $656980 \mathrm{~kg}$ of crude glycerol and $3209071 \mathrm{~kg}$ of cellular debris are produced. Selling them at the rate of $\$ 0.15$ per $\mathrm{kg}$ and $\$ 0.70$ per $\mathrm{kg}$, respectively, will earn additional revenue of 2.34 million $\$$ reducing the net unit production cost to $0.61 \$ / \mathrm{L}$ (Table $4 \mathrm{~b}$ ), which is profitable to the production company as the market price of $\mathrm{B}-10$ biodiesel is $1.20 \$ / \mathrm{L}$.

\subsection{Cost comparison of INRS and conventional process}

The INRS process needs to be compared with the conventional biodiesel production process using microbial lipids in terms of economics. Table $5 \mathrm{a}$ compares the distribution of unit production cost for two processes: INRS process and conventional process. On comparing 
Table $4 b$

Unit and net production cost for B-10 production for INRS process.

\begin{tabular}{|c|c|c|}
\hline \multicolumn{3}{|l|}{ Total investment to start the project } \\
\hline Direct Fixed Capital & 57.28 & Million \$ \\
\hline \multicolumn{3}{|l|}{ Annual Production rates } \\
\hline B-10 & 20 & Million L / year \\
\hline \multicolumn{3}{|l|}{ Annual Operating cost } \\
\hline Annual Operating Cost & 14.46 & Million \$/ year \\
\hline Unit Production Cost & 0.72 & $\$ / \mathrm{L}$ B10 \\
\hline \multicolumn{3}{|l|}{ Additional streams } \\
\hline Crude glycerol & 656980 & $\mathrm{~kg} /$ year \\
\hline Cellular debris (animal feed) & 3209071 & $\mathrm{~kg} /$ year \\
\hline \multicolumn{3}{|l|}{ Additional revenue streams } \\
\hline Crude glycerol & 0.15 & $\$ / \mathrm{kg}$ \\
\hline Animal feed & 0.70 & $\$ / \mathrm{kg}$ \\
\hline Additional revenue & 2.34 & Million \$ / year \\
\hline Net production cost (incorporating revenue) & 12.12 & Million \$ / year \\
\hline Net unit production cost & 0.61 & \$ / L B10 \\
\hline
\end{tabular}

Table 5a

Comparison of biodiesel unit production cost between conventional process and INRS process.

\begin{tabular}{lll}
\hline Process & Conventional & INRS \\
\hline Annual plant capacity & 20 million L & \\
Direct fixed cost (million \$) & 69.43 & 57.28 \\
Distribution of unit production cost & & \\
Fermentation (\$/L) & 2.73 & 0.53 \\
Biomass harvesting (\$/L) & 0.24 & 0.09 \\
Biomass drying (\$/L) & 0.20 & - \\
Lipid recovery (\$/L) & 3.41 & 0.05 \\
Trans-esterification (\$/L) & 0.05 & 0.05 \\
Blending (\$/L) & 0.14 & - \\
Total (\$/L) & $\mathbf{6 . 7 8}$ & $\mathbf{0 . 7 2}$ \\
\hline
\end{tabular}

with the conventional process of biodiesel production using microbial oil, the unit production price in this study is 9.5 times lower than that of conventional process - $\$ 5.90 / \mathrm{kg}$ or $\$ 6.78 / \mathrm{L}$ biodiesel. Also, when comparing the capital investments for two processes, an additional 12.15 million dollars was invested in the conventional process (Table 5a). In the conventional process, expensive equipment like centrifuge (biomass harvesting), the rotary dryer (biomass drying), multi-effect evaporator (lipid extraction) and condenser devices (solvent recovery), blending tank increases the capital investments when compared to INRS process. Additional 12.15 million dollars is required for the purchase, installation and set-up of this additional equipment.

\subsubsection{Fermentation}

It can be observed from Table 5a that in INRS process, fermentation cost has been reduced to nearly $1 / 5$ times of the conventional process. The difference in cost is due to the high purchase cost of glucose $(\$ 0.40 / \mathrm{kg})$, used as a carbon source in the conventional process. Besides, high purchase cost of peptone $(\$ 4.50 / \mathrm{kg}$ ) and yeast extract (\$ $0.80 / \mathrm{kg}$ ), which were used as nitrogen and nutrient source contributed to the high fermentation cost in the conventional process (Koutinas et al., 2014). In INRS process, since the facility was built near the wastewater treatment plant, the sludge transportation cost was assumed zero and the crude glycerol price was $\$ 0.15 / \mathrm{kg}$. The only cost for use of secondary sludge as carbon and nutrient source was to bring the suspended solids to a desired level and washing the sludge solids with tap water. Another factor affecting the fermentation cost is the time of fermentation. The time of fermentation in INRS process was $48 \mathrm{~h}$ while the time of fermentation in conventional process was $134 \mathrm{~h}$. Long pe- riod of fermentation demands high electricity consumption ( $\$ 0.10$ / $\mathrm{kW}$-h), which increases the utility cost. The above discussion clearly indicates that time of fermentation and the cost of carbon and nutrient source is the most significant factors in fermentation. Using waste streams like municipal sludge and crude glycerol during the fermentation reduces the production cost as municipal sludge is a good source of nutrients, carbon and nitrogen source. Hence, there was no need of imparting additional nitrogen in the fermenter.

\subsubsection{Biomass settling}

For biomass settling step, bio-flocculant based settling is economical than centrifuge-based harvesting as the high purchase cost of the bowl centrifuge ( 9 centrifuges with processing capacity of $10 \mathrm{~m}^{3} / \mathrm{h}$ each) leads to high capital investments and facility dependent cost. Also, electricity consumption ( $\$ 0.10 / \mathrm{kW}-\mathrm{h}$ ) during the centrifugation imparts high cost. While in INRS process, the major cost is due to purchase cost of S-EPS ( $\$ 0.95 / \mathrm{L}$ ). The total biomass settling cost of INRS process has been reduced significantly as compared to the conventional process (Table 5a). In the conventional process, after harvesting the biomass is dried and the dried biomass obtained is subjected to lipid extraction. In the biomass drying step, a rotary dryer (specific evaporation rate of 20 $\mathrm{kg} / \mathrm{h} / \mathrm{m}^{3}$ ) is used for biomass drying where steam (\$12/MT steam) is used for biomass drying. In the biomass drying, the major cost contributors are utility cost and the facility dependent cost. However, wet biomass obtained after biomass settling is used directly for lipid extraction without drying. Therefore, the drying step imparts $0 \$ / \mathrm{L}$.

\subsubsection{Lipid extraction}

For lipid extraction step, high extraction cost in the conventional process is due to requirement of large volumes of expensive solvents, chloroform (\$1/kg chloroform) and methanol (\$ $0.24 / \mathrm{kg}$ of methanol) followed by solvent recovery through evaporation and condensation to be used for the next batch, which requires the high electricity consumption ( $\$ 0.10 / \mathrm{kW}-\mathrm{h})$. Steam (\$12/ MT steam) is used for evaporation (multi-effect evaporator) of the solvents while $\mathrm{CaCl}_{2}$ brine (\$ 0.25/MT) was used for solvent recovery through condensation. The purchase of additional equipment like multi-effect evaporator (with evaporation capacity of $16050 \mathrm{~kg} / \mathrm{h}$ ) and a condenser (capacity of $235991 \mathrm{~kg} / \mathrm{h}$ with $90 \%$ recovery) increases the capital investments (as seen in Table 5a) and also the facility dependent cost (which is dependent on capital investment). While in INRS process, the cost is mostly due to raw materials used in the lipid extraction (N-LS and FNA) and recovery (PD). Petroleum diesel used for lipid recovery doesn't need to be evaporated and recovered using a condenser. It is also used for the blending of biodiesel in the trans-esterification step itself and eliminates the additional blending step. Therefore, the lipid extraction cost is significantly lower in INRS process than the conventional process. Another conclusion can be drawn on time of the cell wall disruption process. The conventional cell wall disruption process using organic solvents was conducted for $4 \mathrm{~h}$ (Yellapu et al., 2016) followed by $1 \mathrm{~h}$ separation of cellular debris and solvent-liquid mixture and then $8 \mathrm{~h}$ of solvent evaporation and recovery (total time of $13 \mathrm{~h}$ ). The INRS lipid extraction process was conducted for $1 \mathrm{~h}$ duration only followed by $1 \mathrm{~h}$ of phase separation. Larger cell disruption time will increase the energy input due to agitation and mixing and hence the utility cost. While in INRS process, the faster the process (short fermentation time and faster lipid extraction process) results in a greater number of batches annually.

\subsubsection{Trans-esterification}

For trans-esterification step, nearly similar cost (\$ 0.05/ L B10) was observed for both INRS and conventional process. Although $\mathrm{NaOH}$ (\$ $0.50 / \mathrm{kg} \mathrm{NaOH}$ ), used in conventional process is costlier than $\mathrm{H}_{2} \mathrm{SO}_{4}$ ( $\$ 0.35 / \mathrm{kg} \mathrm{H}_{2} \mathrm{SO}_{4}$ ), the acid-catalyzed trans-esterification process is 
a lengthy process affecting the utility cost. These two items (high $\mathrm{NaOH}$ cost in conventional process and high utility cost in INRS process) balance each other and trans-esterification cost is nearly same. However, additional blending step (blending of biodiesel with petroleum diesel) in the conventional process accounts for $0.14 \$$ / L B10, which is eliminated in INRS process because lipid recovery is performed using petroleum diesel (in lipid extraction step). In conventional process, the additional cost for drying (\$ 0.20/L B10) and blending (\$ 0.14/L B10) will have significant impact on the annual operating cost (additional operating cost of 6.80 million\$/ year in conventional process).

\subsubsection{Biodiesel purification}

Currently, purification studies are being conducted for biodiesel obtained from sludge cultivated microbial oil in INRS lab. Several methods have been reported in the literature for biodiesel purification - dry washing, wet-washing and membrane technology. In wet-washing technique, biodiesel is washed with acid/ water, followed by centrifugation and this step is repeated several times until purified biodiesel is obtained. Hence, wet-washing techniques have large capital investments and they are unable to purify biodiesel (water content, especially) as required by American society for testing and materials (ASTM) standards (Banga et al., 2014; Berrios et al., 2011). In membrane technology, the membrane cost is a major contributing factor in the biodiesel purification cost, which needs to be replaced after a certain time. Also, fouling of organic membrane can occur easily due to high soap content in crude biodiesel (Yellapu et al., 2018). In dry-washing techniques, adsorbents like Magnesol $\AA$, SIPERNAT $®$ and resins like LEWATIT $\AA$, AMBERLITE $\AA$ have been reported for biodiesel purification (Yellapu et al., 2018). Dry-washing technique has lower capital investments as compared to other purification techniques. However, the cost of resin (which needs to be replaced after a certain time) and resin regeneration (using solvents) are major cost contributing factors in dry-washing technique. Resins and ceramic membranes are more efficient when compared to the wet-washing technique as they do not impart moisture and acidity to the purified biodiesel (Banga et al., 2014; Faccini et al., 2011). Research is undergoing at the INRS lab to optimize the regeneration cycle of the membrane and the resins for biodiesel purification.

The microbial biodiesel production cost using waste as carbon source (0.72 \$/L) is competitive to biodiesel cost produced using vegetable oils (1.15 \$/L) and waste cooking oil (0.85 \$/L) (Apostolakou et al., 2009; Zhang et al., 2003). In another study, the unit cost for biodiesel production using oil extracted from sludge followed by trans-esterification was 0.59 \$/L biodiesel (Chen et al., 2018a). However, the process reported by Chen et al. (2018a) has a disadvantage that oil content in sludge varies from batch to batch, which signifies a large variability in efficacy of biodiesel production from sludge. Fermentation is the most cost contributing step in INRS process. Hence, it is important to find out which fermentation parameters will have more impact on the biodiesel production cost.

\subsection{Sensitivity analysis for INRS process}

\subsubsection{Plant capacity}

The equipment cost for higher capacities plant was carried out by power law model using Eq. (6).

$C=C_{o}\left(\frac{S}{S_{0}}\right)^{n}$

where c, s and $\mathrm{n}$ are cost of equipment, size of equipment and size exponent factor, respectively. The $\mathrm{n}$ value normally falls between 0.5 and 1.0 with an average value for vessels of around 0.6 (Chen et al., 2018a; Ram et al., 2018).
Increasing the plant capacity from 5 million L/ year to 100 million $\mathrm{L} /$ year decreases the unit production cost from 1.27 \$/ L to 0.615 \$/ $\mathrm{L}$ (51.6\% reduction). If the sale of crude glycerol and cellular debris is considered, the net unit production decreases from 1.02 \$ L (5 million $\mathrm{L})$ to $0.55 \$ / \mathrm{L}(100$ million $\mathrm{L})$. Payback period is the time within which the capital investments are recovered from the profit earned by the company. For an enterprise to be profitable, the unit production price should be lower than the unit selling price of the product, ROI should be positive and payback period should be minimum. For plant capacity greater than 50 million L, ROI is greater than $20 \%$ and payback time is less than 5 years, which is a profitable scenario for the investor (Fig. 3a and b). Hence, while setting up a new facility, the manufacturer should keep a perspective of plant capacity and the market demand.

\subsubsection{Inoculum size}

For T. oleaginosus, $10 \%(\mathrm{v} / \mathrm{v})$ has been reported in literature for the optimum lipid production (Zhang et al., 2018). Inoculum size is an important parameter to verify its impact on the unit production cost because fermentation is a major cost contributing factor. On decreasing the inoculum volume $(\% \mathrm{v} / \mathrm{v})$, the equipment purchase cost and capital investments are decreased (Table $5 \mathrm{~b}$ ). Moreover, the reduction in inoculum volume $(\% \mathrm{v} / \mathrm{v})$ reduces the facility dependent cost along with labour cost as it reduces the number of seed fermenters. Assuming similar lipid concentration in the fermented broth, reducing the inoculum volume $(\% \mathrm{v} / \mathrm{v})$ from 10 to 1 reduces the unit production cost from $\$ 0.72 / \mathrm{L}$ to $\$ 0.70 / \mathrm{L}(2.78 \%$ reduction) and capital investments from 57.28 million $\$$ to 52.14 million $\$$. The difference in unit production cost may appear very small, but a difference of 5.14 million dollars in the capital cost is significant.

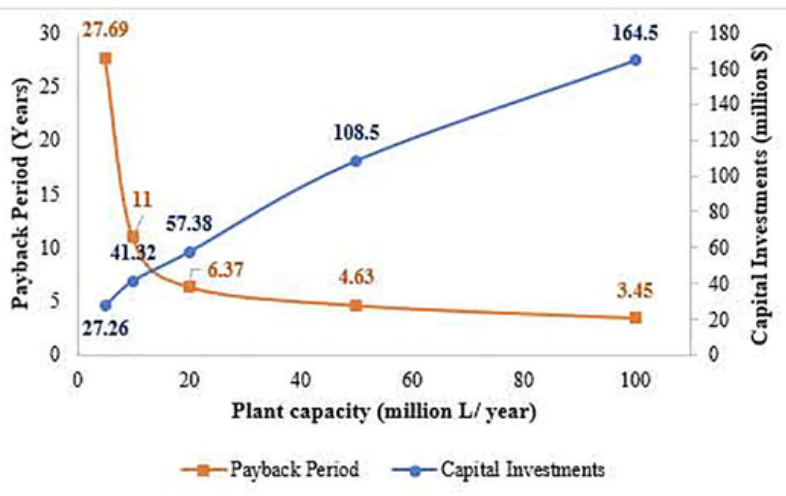

a)

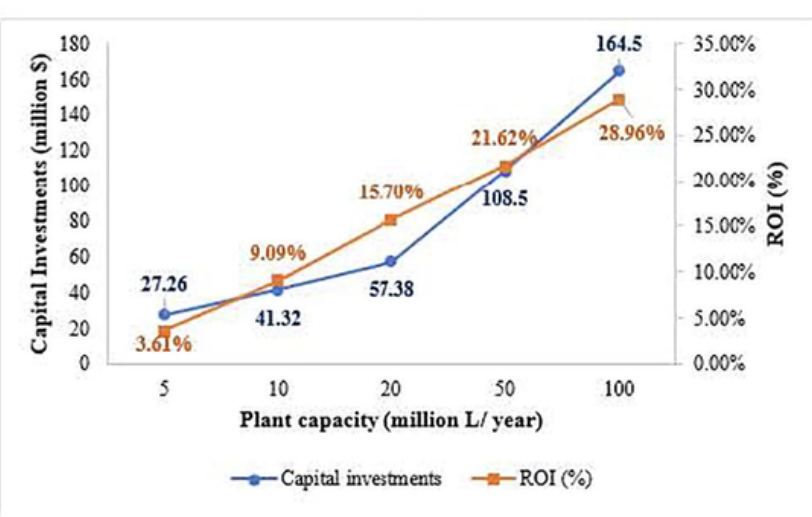

b)

Fig. 3. Impact of plant capacity on a) Payback period and b) Return on investment (ROI). 
Table 5b

B-10 price sensitivity to inoculum size.

\begin{tabular}{llllll}
\hline Inoculum \% & $1 \%$ & $2 \%$ & $5 \%$ & $10 \%$ & $\mathrm{v} / \mathrm{v}$ \\
\hline Equipment purchase cost & 14.27 & 14.5 & 14.99 & 15.68 & Million \$ \\
Direct Fixed Capital & 52.14 & 53.98 & 54.76 & 57.28 & Million \$ \\
No of seed fermenters & 3 & 4 & 4 & 6 & \\
Annual Operating Cost & 14 & 14.2 & 14.35 & 14.46 & Million \$/ year \\
Unit Production Cost & $\mathbf{0 . 7 0}$ & $\mathbf{0 . 7 1}$ & $\mathbf{0 . 7 2}$ & $\mathbf{0 . 7 2}$ & \$/ L B10 \\
\hline
\end{tabular}

In the above scenario, it was assumed that changing the inoculum size will not affect lipid concentration and biomass lipid content. But it is not true in real practice. In one of the studies in authors lab, the impact of inoculum size was investigated on lipid concentration and lipid content in shake-flask studies using Y. Lipolytica (Mathiazhakan et al., 2016). Inoculum size of $2.50 \%$ resulted in lipid concentration of $3.20 \mathrm{~g} /$ $\mathrm{L}$ and $35.55 \%$ biomass lipid content while inoculum size of $10 \%$ resulted in lipid concentration of $4.24 \mathrm{~g} / \mathrm{L}$ and $42.57 \%$ biomass lipid content at $72 \mathrm{~h}$. However, inoculum size of $6.25 \%$ resulted in $5.1 \mathrm{~g} / \mathrm{L}$ and $50 \%$ biomass lipid content at $72 \mathrm{~h}$. Inoculum size impacts lipid concentration and lipid productivity in the fermenter, which ultimately impacts the biodiesel unit production cost.

\subsubsection{Lipid productivity}

The effect of lipid concentration and fermentation time can be combined into lipid productivity (lipid concentration per unit time). It was revealed that increasing lipid productivity from $0.31 \mathrm{~g} / \mathrm{L} / \mathrm{h}$ to $0.60 \mathrm{~g} / \mathrm{L} /$ $\mathrm{h}$, reduced B10 unit production cost from 0.95 \$/L to $\$ 0.64 / \mathrm{L}(32.6 \%$ reduction). Lipid productivity governs the size of the fermenter, time of fermentation, number of batches produced annually, quantity of B10 produced per batch, the amount of substrate used for fermentation (as the size of fermenter increases, substrate requirement and raw material cost also increase). Lipid productivity is the most cost impacting factor for B10 production. The maximum lipid productivity attained in this study was $0.36 \mathrm{~g} / \mathrm{L} / \mathrm{h}(17.37 \mathrm{~g} / \mathrm{L}$ lipid in $48 \mathrm{~h})$ for which $\mathrm{B} 10$ unit production cost was estimated to be $\$ 0.72 / \mathrm{L}$. If lipid productivity is increased to $0.60 \mathrm{~g} / \mathrm{L} / \mathrm{h}$ during the fermentation, B10 unit production cost can be brought down to $0.64 \$ / \mathrm{L}$. Research is ongoing in INRS laboratory to increase the lipid productivity in fermentation conducted with sludge fortified with crude glycerol as raw material.

Koutinas et al. (2014) reported the effect of lipid productivity on unitary microbial oil (MO) cost. It was reported that if the fermenter/ lipid productivity is increased from $0.54 \mathrm{~g} / \mathrm{L} / \mathrm{h}$ to $1.08 \mathrm{~g} / \mathrm{L} / \mathrm{h}$, the $\mathrm{MO}$ unit cost decreased from $\$ 5.5 / \mathrm{kg}$ to $\$ 4.50 / \mathrm{kg}$ ( $18.18 \%$ reduction). A further increase in the fermenter/ lipid productivity has a less profound effect on unitary costs.

\subsubsection{Cost of EPS used during biomass settling}

Since the cost contribution of EPS is $60 \%$ of the raw material acquisition cost, the production cost of S-EPS can have significant impact on biodiesel (B-10) production cost. The current S-EPS cost has been considered 0.95\$/ L (SuperPro Designer v10) for which B10 unit production cost of $\$ 0.72 / \mathrm{L}$ has been calculated. If S-EPS cost can further be decreased to $\$ 0.33$ (by optimizing the EPS fermentation process parameters like EPS productivity and inoculum size), the unit B10 production cost can be brought down to $\$ 0.63 / \mathrm{L}$.

S-EPS (obtained after centrifugation of EPS fermentation broth) was used for biomass settling in cost simulations. Powder EPS, which is obtained after drying of S-EPS is costlier as drying process (12 \$/MT steam) further increases EPS production cost. The S-EPS cost of $0.95 \$ /$ $\mathrm{L}$ has been considered assuming $60 \mathrm{~g} / \mathrm{L}$ EPS during production process. The research is ongoing in our lab to reduce EPS production cost and emphasis has been laid on increasing the EPS concentration during production process by adopting co-fermentation of sludge and crude glycerol.

\subsection{GHG emission of INRS process}

To investigate environmental impact of the INRS process, GHG balance needs to be performed. GHG emission accounts for $\mathrm{CO}_{2}, \mathrm{CH}_{4}$, and $\mathrm{N}_{2} \mathrm{O}$ emissions originated from specific sources of energy and materials consumed, which include the use of fuels, electricity, and chemicals. Intergovernmental Panel on Climate Change (IPCC) global warming potentials are applied to $\mathrm{CH}_{4}\left(21 \mathrm{CO}_{2}\right.$-eq) and $\mathrm{N}_{2} \mathrm{O}\left(310 \mathrm{CO}_{2}\right.$-eq $)$ emissions to calculate the $\mathrm{CO}_{2}$ equivalent $\left(\mathrm{CO}_{2}\right.$-eq) emissions of the biodiesel production processes. The positive/negative value of the calculation represents that the process produces/captures GHG emissions.

GHG emission calculations account for the production of raw materials, their transportation using diesel fuel $\left(0.11 \mathrm{~kg} \mathrm{CO}_{2} / \mathrm{km} /\right.$ tonne $)$, construction of the industry with auxiliary facilities, electricity used during manufacturing, transportation of product and by product along with use of blended biodiesel as fuel. Emission coefficients of electricity, fuel used in transportation and raw materials production have been taken from Zhang et al. (2013). Transportation of raw materials and by-product (cellular debris) has been considered within $100 \mathrm{~km}$ distance. Transportation of blended biodiesel has been considered using pipelines for which no GHG emission occurs. The GHG coefficient for construction of industry and demolition has been taken from Yan et al. (2010). Total GHG emission to produce 20 million L biodiesel (B-10) has been calculated to be 76 219-tonne $\mathrm{CO}_{2}$ eq. (Table 6). Out of which, $77.60 \%$ GHG emission was contributed from diesel, which was used for lipid extraction and blending and is also used as fuel. This was followed by industry construction and demolition over the area of 5 acres $\left(20234.3 \mathrm{~m}^{2}\right)$ (10.03\%) (Yan et al., 2010). This was followed by the use of biodiesel as fuel, which contributes $6.46 \%$ of total GHG emissions. Raw materials contribute $5.24 \%$ of GHG emissions. The INRS process also reduces $\mathrm{CO}_{2}$ emission by:

a. Saving Fuel in sludge transportation to disposal site

b. Emission of carbon dioxide from sludge land filling. Sludge land filling produces decomposition gases ( $\mathrm{CO}_{2}$ and methane).

c. Use of crude glycerol from biodiesel industry rather than use of pure glycerol.

d. Replacement of diesel by biodiesel.

e. Energy savings by the replacement of conventional process by INRS process. Energy savings of $102 \mathrm{GJ} /$ tonne B10 accounts for 8.94-tonne CO2 eq./tonne B10.

After accounting the credits of sludge land filling and replacement of the conventional process, net $\mathrm{CO}_{2}$ capture of the process is 10.78 -tonne $\mathrm{CO}_{2}$ eq./ tonne B10. The negative value of GHG emission or positive value of GHG capture reveals that the INRS process is environmentally friendly. Campbell et al. (2011) have reported that GHG emission per ton/ $\mathrm{km}$ for canola was $35.90 \mathrm{~g} \mathrm{CO}_{2}$ eq., which was positive and has negative environmental impact. While for diesel and algae-based biodiesel, GHG emission per tonne/ $\mathrm{km}$ was 3.80 and $4.80 \mathrm{~g} \mathrm{CO}_{2}$ eq., respectively (Campbell et al., 2011). GHG capture for the biodiesel production process using sludge (oil extraction from sludge followed by trans-esterification) was 26.19 tons $\mathrm{CO}_{2}$ eq./ tonne biodiesel (Zhang et al., 2013). However, the process reported by Zhang et al. (2013) has a disadvantage that oil content in sludge varies from batch to batch, which signifies a large variability in efficacy of biodiesel production from sludge. Thus, the INRS process is economical, energetically favorable and environmentally friendly as compared to the conventional biodiesel process using microbial lipid. 
Table 6

GHG emission of INRS process (2 million L FAME and 18 million L PD).

\begin{tabular}{|c|c|c|c|c|c|}
\hline \multicolumn{2}{|l|}{ Components } & $\begin{array}{l}\text { Rate } \\
\text { (kg } \\
\mathrm{CO}_{2} \\
\text { eq./ } \\
\text { tonne) }\end{array}$ & $\begin{array}{l}\text { Qty } \\
\text { (tonne) }\end{array}$ & $\begin{array}{l}\text { tonne } \\
\mathrm{CO}_{2} \\
\text { eq. }\end{array}$ & $\%$ \\
\hline \multicolumn{2}{|c|}{ Electricity (kg CO 2 eq./kW-h) } & 0.0014 & $\begin{array}{l}18714 \\
415 \mathrm{~kW}-\mathrm{h}\end{array}$ & 26 & 0.03 \\
\hline \multirow{7}{*}{$\begin{array}{l}\text { Raw Material } \\
\text { Production }\end{array}$} & $\mathrm{NaOH}$ & 469.30 & 300 & 141 & 0.18 \\
\hline & Sulphuric Acid & 207.70 & 338 & 70 & 0.09 \\
\hline & EPS & $\begin{array}{l}8 \\
907.15\end{array}$ & 202 & 1797 & 2.36 \\
\hline & $\begin{array}{l}\text { Calcium } \\
\text { chloride }\end{array}$ & $\begin{array}{l}1 \\
030.20\end{array}$ & 646 & 666 & 0.87 \\
\hline & N-LS & 947 & 101 & 955 & 0.13 \\
\hline & FNA & 831.70 & 50 & 419 & 0.05 \\
\hline & Methanol & $\begin{array}{l}1 \\
981.44\end{array}$ & 598 & 1184 & 1.55 \\
\hline $\begin{array}{l}\text { Raw material } \\
\text { transportation }\end{array}$ & Transportation & 11 & 40116 & 441 & 0.58 \\
\hline \multicolumn{2}{|c|}{$\begin{array}{l}\text { Industry construction and } \\
\text { demolition }\left(\mathrm{kg} \mathrm{CO}_{2} \text { eq. } / \mathrm{m}^{2}\right)\end{array}$} & 378 & $\begin{array}{l}20 \\
234.3 \mathrm{~m}^{2}\end{array}$ & 7649 & 10.03 \\
\hline \multirow{2}{*}{$\begin{array}{l}\text { Product } \\
\text { Distribution }\end{array}$} & B10 & 0 & 17400 & 0 & 0 \\
\hline & $\begin{array}{l}\text { Animal feed } \\
\text { (Cellular } \\
\text { Debris) }\end{array}$ & 11 & 3209 & 353 & 0.05 \\
\hline \multirow{3}{*}{$\begin{array}{l}\text { Use of B10 } \\
\text { Biodiesel }\end{array}$} & FAME $(10 \%)$ & 2830 & 1740 & 4924 & 6.46 \\
\hline & Petroleum & 3777 & 15660 & 59 & 77.6 \\
\hline & Diesel (90\%) & & & 148 & \\
\hline \multicolumn{3}{|c|}{ Total GHG emission (tonne $\mathrm{CO}_{2}$ eq.) } & & 76219 & \\
\hline \multirow[t]{5}{*}{ Credits } & $\begin{array}{l}\text { Sludge to } \\
\text { landfill }\end{array}$ & 29400 & 3486 & 102488 & \\
\hline & $\begin{array}{l}\text { Diesel for } \\
\text { sludge } \\
\text { transportation }\end{array}$ & 11 & 3486 & 38 & \\
\hline & $\begin{array}{l}\text { Use of crude } \\
\text { glycerol }\end{array}$ & 1.66 & 3998 & 7 & \\
\hline & $\begin{array}{l}\text { Diesel } \\
\text { replacement } \\
\text { by biodiesel }\end{array}$ & 3220 & 1740 & 5603 & \\
\hline & $\begin{array}{l}\text { Replacement } \\
\text { of } \\
\text { conventional } \\
\text { process by } \\
\text { INRS process }\end{array}$ & 8943 & 17400 & 167040 & \\
\hline \multicolumn{3}{|c|}{ GHG emission saved (tonne $\mathrm{CO}_{2}$ eq.) } & & 263738 & \\
\hline \multicolumn{3}{|c|}{ Net GHG capture (tonne $\mathrm{CO}_{2}$ eq.) } & & 187519 & \\
\hline \multicolumn{3}{|c|}{ Net GHG capture (tonne $\mathrm{CO}_{2}$ eq./ tonne $\mathrm{B} 10$ ) } & & 10.78 & \\
\hline
\end{tabular}

\section{Conclusion}

In this study, economic assessment was carried out for blended biodiesel B-10 production. In INRS process, microbial lipid was produced in fermentation by $T$. oleaginosus using washed sludge fortified with crude glycerol while lipid was extracted from wet biomass using bio-degradable surfactant and PD. When compared to the conventional process, major reduction in cost was observed during fermentation and lipid extraction step. Lipid productivity during fermentation was the main process parameter affecting the B-10 unit production cost. The manufacturer should target 50 million L plant capacity for high profitability. INRS process is energetically favorable and results in positive GHG capture.

\section{Declaration of Competing Interest}

The authors declare that they have no known competing financial interests or personal relationships that could have appeared to influence the work reported in this paper.

\section{Acknowledgements}

Authors would like to acknowledge the Natural Sciences and Engineering Research Council of Canada (grant A4984 and Canada Research Chair) for financial support. Authors would like to acknowledge Aishwarya Pandey (INRS-ETE) for English corrections.

\section{References}

Apostolakou, A., Kookos, I., Marazioti, C., Angelopoulos, K., 2009. Techno-economic analysis of a biodiesel production process from vegetable oils. Fuel Process. Technol. 90 (7-8), 1023-1031.

Banga, S., Varshney, P., Kumar, N., Pal, M., 2014. Optimization of parameters for purification of jatropha curcas based biodiesel using organic adsorbents. Int. J. Renew. Energy Res. (IJRER) 4 (3), 598-603.

Berrios, M., Martín, M., Chica, A., Martín, A., 2011. Purification of biodiesel from used cooking oils. Appl. Energy 88 (11), 3625-3631.

Campbell, P.K., Beer, T., Batten, D., 2011. Life cycle assessment of biodiesel production from microalgae in ponds. Bioresour. Technol. 102 (1), 50-56.

Chen, J., Tyagi, R.D., Li, J., Zhang, X., Drogui, P., Sun, F., 2018. Economic assessment of biodiesel production from wastewater sludge. Bioresour. Technol. 253, 41-48.

Chen, J., Yan, S., Zhang, X., Tyagi, R.D., Surampalli, R.Y., Valéro, J., 2018. Chemical and biological conversion of crude glycerol derived from waste cooking oil to biodiesel. Waste Manage. 71, 164-175.

Dassey, A.J., Theegala, C.S., 2013. Harvesting economics and strategies using centrifugation for cost effective separation of microalgae cells for biodiesel applications. Bioresour Technol 128, 241-245.

Dong, T., Knoshaug, E.P., Pienkos, P.T., Laurens, L.M., 2016. Lipid recovery from wet oleaginous microbial biomass for biofuel production: a critical review. Appl. Energy 177, 879-895.

Faccini, C.S., Cunha, M.E.d., Moraes, M.S.A., Krause, L.C., Manique, M.C., Rodrigues, M.R.A., Benvenutti, E.V., Caramão, E.B. 2011. Dry washing in biodiesel purification: a comparative study of adsorbents. J. Brazilian Chem. Soc. 22(3), 558-563.

Kim, J., Yoo, G., Lee, H., Lim, J., Kim, K., Kim, C.W., Park, M.S., Yang, J.-W., 2013. Methods of downstream processing for the production of biodiesel from microalgae. Biotechnol. Adv. 31 (6), 862-876.

Koutinas, A.A., Chatzifragkou, A., Kopsahelis, N., Papanikolaou, S., Kookos, I.K., 2014. Design and techno-economic evaluation of microbial oil production as a renewable resource for biodiesel and oleochemical production. Fuel 116, 566-577.

Kumar, L.R., Yellapu, S.K., Tyagi, R.D., Zhang, X., 2019. A review on variation in crude glycerol composition, bio-valorization of crude and purified glycerol as carbon source for lipid production. Bioresour. Technol. 293, 122155

Kumar, L.R., Yellapu, S.K., Zhang, X., Tyagi, R.D., 2019. Energy balance for biodiesel production processes using microbial oil and scum. Bioresour. Technol. 272, 379-388.

Kumar, L.R., Ndao, A., Valéro, J., Tyagi, R.D., 2019. Production of Bacillus thuringiensis based biopesticide formulation using starch industry wastewater (SIW) as substrate: a techno-economic evaluation. Bioresour. Technol. 294, 122144.

Kuttiraja, M., Douha, A., Valéro, J.R., Tyagi, R.D., 2016. Elucidating the Effect of Glycerol Concentration and C/N Ratio on Lipid Production Using Yarrowia lipolytica SKY7. Appl. Biochem. Biotechnol. 180 (8), 1586-1600.

le Maire, M., Champeil, P., MÖller, J.V., 2000. Interaction of membrane proteins and lipids with solubilizing detergents. Biochimica et Biophysica Acta (BBA)-Biomembranes 1508(1-2), 86-111.

Mathiazhakan, K., Ayed, D., Tyagi, R.D., 2016. Kinetics of lipid production at lab scale fermenters by a new isolate of Yarrowia lipolytica SKY7. Bioresour. Technol. 221, 234-240.

Nouha, K., Hoang, N., Song, Y., Tyagi, R., Surampalli, R., 2016. Characterization of Extracellular Polymeric Substances (Eps) Produced by Cloacibacterium normanense Isolated from Wastewater Sludge for Sludge Settling and Dewatering 5, 6.

Nouha, K., Kumar, R.S., Balasubramanian, S., Tyagi, R.D., 2018. Critical review of EPS production, synthesis and composition for sludge flocculation. J. Environ. Sci. 66, 225-245.

Phadnis, S., Satpati, A., Muthe, K., Vyas, J., Sundaresan, R., 2003. Comparison of rolled and heat treated SS304 in chloride solution using electrochemical and XPS techniques. Corros. Sci. 45 (11), 2467-2483.

Ram, S., Kumar, L., Tyagi, R., Drogui, P., 2018. Techno-economic evaluation of simultaneous production of extra-cellular polymeric substance (EPS) and lipids by Cloacibacterium normanense NK6 using crude glycerol and sludge as substrate. Water Sci. Technol. 77 (9), 2228-2241.

Salim, S., Vermuë, M., Wijffels, R., 2012. Ratio between autoflocculating and target microalgae affects the energy-efficient harvesting by bio-flocculation. Bioresour. Technol. 118, 49-55.

Vasileva-Tonkova, E., Galabova, D., Karpenko, E., Shulga, A., 2001. Biosurfactant-rhamnolipid effects on yeast cells. Lett. Appl. Microbiol. 33 (4), 280-284. 
Wu, J., Yang, Q., Luo, W., Sun, J., Xu, Q., Chen, F., Zhao, J., Yi, K., Wang, X., Wang, D., 2018. Role of free nitrous acid in the pretreatment of waste activated sludge: extracellular polymeric substances disruption or cells lysis? Chem. Eng. J. 336, 28-37.

Yan, H., Shen, Q., Fan, L.C., Wang, Y., Zhang, L., 2010. Greenhouse gas emissions in building construction: a case study of One Peking in Hong Kong. Build. Environ. 45 (4), 949-955.

Yellapu, S.K., Bezawada, J., Kaur, R., Kuttiraja, M., Tyagi, R.D., 2016. Detergent assisted lipid extraction from wet yeast biomass for biodiesel: a response surface methodology approach. Bioresour. Technol. 218, 667-673.

Yellapu, S.K., Kaur, R., Kumar, L.R., Tiwari, B., Zhang, X., Tyagi, R.D., 2018. Recent developments of downstream processing for microbial lipids and conversion to biodiesel. Bioresour. Technol. 256, 515-528.

Yellapu, S.K., Kaur, R., Tyagi, R.D., 2017. Detergent assisted ultrasonication aided in situ transesterification for biodiesel production from oleaginous yeast wet biomass. Bioresour. Technol. 224, 365-372.

Yellapu, S.K., Kaur, R., Tyagi, R.D., 2019. Oil extraction from scum and ex situ transesterification to biodiesel. Biofuels 1-8.

Yellapu, S.K., Klai, N., Kaur, R., Tyagi, R.D., Surampalli, R.Y., 2019. Oleaginous yeast biomass flocculation using bioflocculant produced in wastewater sludge and transesterification using petroleum diesel as a co-solvent. Renew. Energy 131, 217-228.
Yu, G.-H., He, P.-J., Shao, L.-M., 2009. Characteristics of extracellular polymeric substances (EPS) fractions from excess sludges and their effects on bioflocculability. Bioresour. Technol. 100 (13), 3193-3198.

Zhang, X., Chen, J., Idossou, V., Tyagi, R.D., Li, J., Wang, H., 2018. Lipid accumulation from Trichosporon oleaginosus with co-fermentation of washed wastewater sludge and crude glycerol. Fuel 226, 93-102.

Zhang, X., Chen, J., Wu, D., Li, J., Tyagi, R.D., Surampalli, R.Y., 2019. Economical lipid production from Trichosporon oleaginosus via dissolved oxygen adjustment and crude glycerol addition. Bioresour. Technol. 273, 288-296.

Zhang, X., Chen, J., Yan, S., Tyagi, R.D., Surampalli, R.Y., Li, J., 2017. Lipid Production for Biodiesel from Sludge and Crude Glycerol. Water Environ. Res. 89 (5), 424-439.

Zhang, X., Yan, S., Tyagi, R.D., Surampalli, R.Y., 2013. Energy balance and greenhouse gas emissions of biodiesel production from oil derived from wastewater and wastewater sludge. Renew. Energy 55, 392-403.

Zhang, X., Yan, S., Tyagi, R.D., Surampalli, R.Y., Valéro, J.R., 2016. Energy balance of biofuel production from biological conversion of crude glycerol. J. Environ. Manage. 170, 169-176.

Zhang, Y., Dubé, M.A., McLean, D.D., Kates, M., 2003. Biodiesel production from waste cooking oil: 2. Economic assessment and sensitivity analysis. Bioresour. Technol. 90 (3), 229-240. 